Serie B, Nr. 3

Geological Survey of Denmark. Series B, No. 3

\title{
The Upper Triassic - Lower Jurassic Vinding and Gassum Formations of the Norwegian-Danish Basin
}

BY

Finn Bertelsen

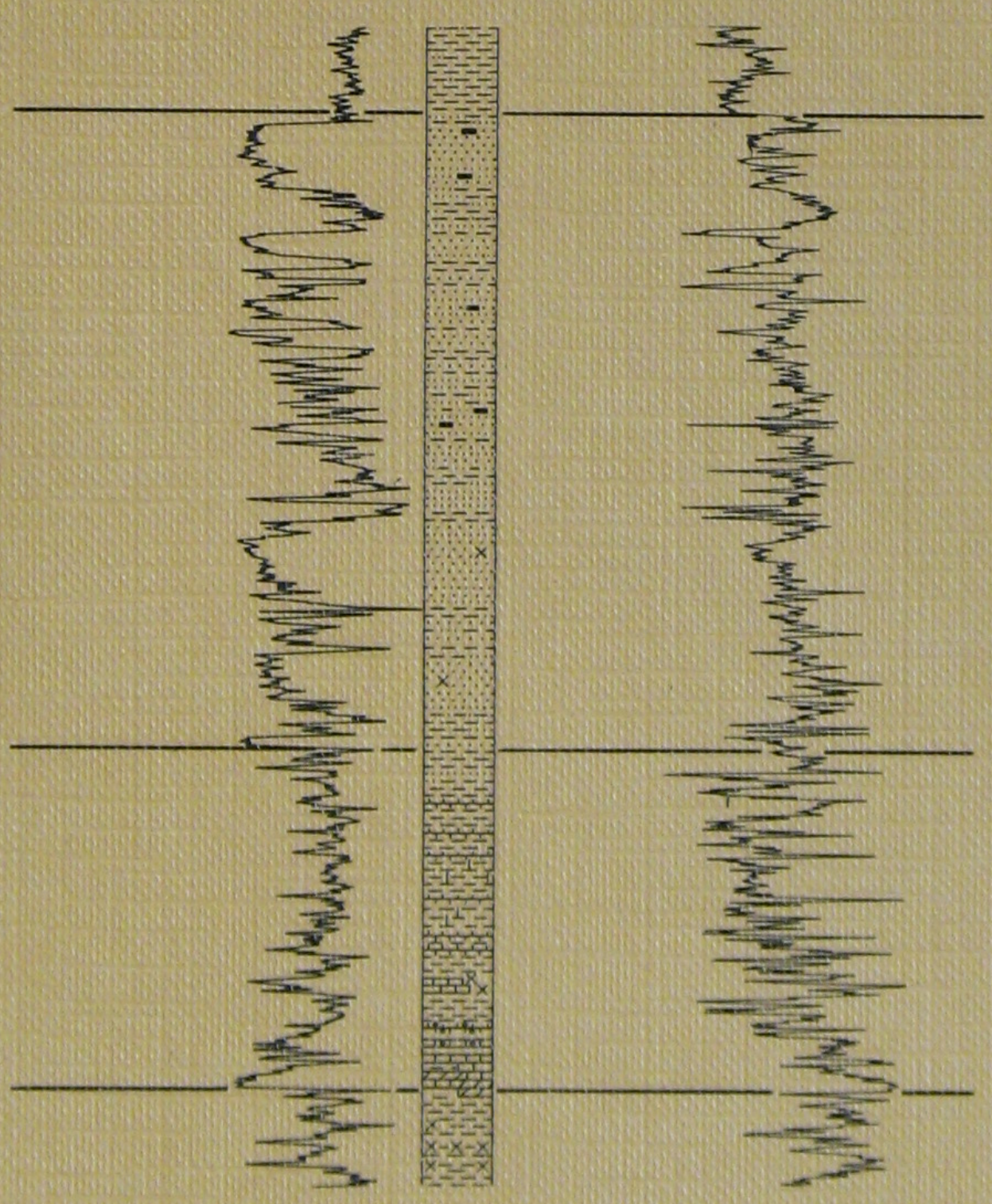




\section{The Upper Triassic - Lower Jurassic Vinding and Gassum Formations of the Norwegian-Danish Basin}

by

Finn Bertelsen 
D.G.U. Serie B, nr. 3

er sat med Foto Times

og trykt i offset i 1000 eksemplarer

hos C. A. Backhausen ApS, København.

Bogen er trykt på Thai-Cote, $115 \mathrm{~g}$

fra A/S De Forenede Papirfabrikker.

ISBN 87-421-0717-2

Date of publication: 1978-12-22

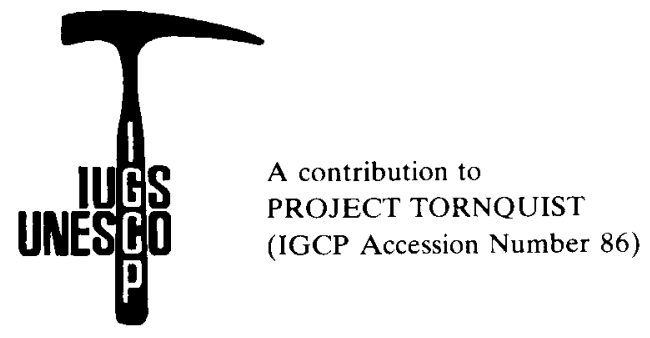




\section{Contents}

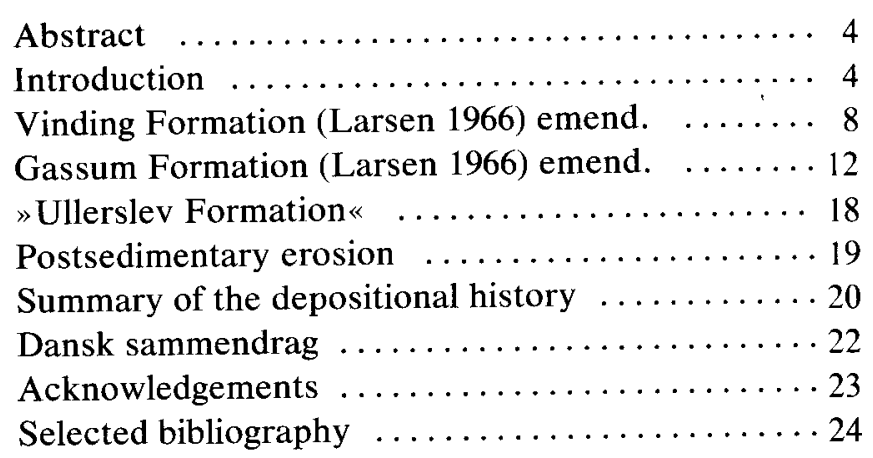




\section{Abstract}

The late Triassic-early Jurassic Vinding and Gassum Formations are redefined and mapped within the Norwegian-Danish Basin. The Vinding Formation is a brackish marine shallow water deposit restricted to the Danish Subbasin. It is of late Norian-Rhaetian age. The Gassum Formation is a fluvio-deltaic to near-shore marine, arenaceous deposit carried from north and east into the basin. Its upper part is diachronous, ranging in age from Rhaetian in the basin center to late Sinemurian in the northern margin. It is proposed that the Ullerslev Formation is repealed. The parallelism between the course of sedimentation in the Norwegian-Danish Basin, the North German Basin and the Polish Basin indicates eustatic sea level changes to be of greater importance than local tectonic events.

\section{Introduction}

The onshore drilling activity for hydrocarbons in Denmark (map fig. 1) has for many years been concentrated on Mesozoic sandstone reservoirs and/or Zechstein carbonates. Among the main objectives have been the Rhaetic sandstones, named the Gassum Formation by Larsen (1966), of the Danish Subbasin (fig. 2), which forms the eastern part of the Norwegian-Danish Basin. In recent years some offshore wells were also drilled on analogous prospects, i.e. on closures formed over the crests of the many structures of Zechstein salt confined to the central part of the basin (fig. 2).

Commonly the drilling was abandoned when the top of the Triassic Keuper red beds was penetrated, and after drilling through the dark grey claystones of the Vinding Formation. Since the naming of the Vinding and Gassum Formations by Larsen in 1966, much new information has been obtained on both the lithology and palaeontology of the two formations, and it was felt necessary to redefine the units. A demand for a mapping of the Gassum Formation in connection with the setting up of pilot projects for utilization of geothermal energy further stimulated efforts to work up the new material. Due to the lack of sufficient control points the maps presented must be regarded as provisional and generalized. Also the effect of halokinetic movements in the Zechstein salt has been neglected, although some pillow formation is noted already in the Upper Triassic Keuper, as evidenced by seismics.
The purpose of the present paper is to give a redescription and redefinition of the Vinding and Gassum Formations and thereby contribute to a clarification of the lithostratigraphy of the late Triassicearly Jurassic deposits of the Norwegian-Danish Basin. The study is mainly based on a re-evaluation of existing wire line logs, lithological and biostratigraphical reports and the published information given in the literature list. The biostratigraphical evaluation is mainly based on published and unpublished ostracod studies by O. Bruun Christensen (DGU) and O. Michelsen (DGU), and on palynological studies by the present author. It has however been necessary to carry out supplementary palynological analyses of the Gassum Formation in the poorly dated northernmost wells of Jylland.

The two formations were described and named by Larsen (1966), who considered them contemporaneous. The Vinding Formation was regarded as the basinal marine claystones, whereas the Gassum Formation was described as a marginal fluvio-deltaic deposit. In accordance with the biostratigraphical results published in Sorgenfrei \& Buch (1964) both formations were referred to the Rhaetic sensu germanico. The original description of the formations is quoted below. Larsen also defined the Ullerslev Formation as a local Rhaetic deltaic deposit fringing part of the Ringkøbing-Fyn High, part of which was thought to have formed an island in the Rhaetian sea.

Christensen (1962, 1963, 1971 and 1973) dealt with the ostracod faunas of the Vinding Formation (as defined in the present paper) in a number of wells. The recovered faunas compare well with contemporaneous German assemblages. In a paper from 1972, Christensen maintained Larsen's concepts with regard to the Rhaetic facies distribution. He further demonstrated the typical presence of oolitic limestones in the lower transgressive part of the Rhaetic.

Bertelsen \& Michelsen (1970) studied the megaspore and ostracod assemblages of the RhaeticLower Jurassic section in the Rødby 1 well. The Triassic-Jurassic boundary can be defined rather precisely by a change in the megaspore assemblage.

Michelsen, who has described the Lower Jurassic litho- and biostratigraphy of the Norwegian-Danish Basin in several publications (1973, 1975, 1978 a.o.), demonstrated the diachronous nature of the Gassum Formation; that is, he showed the upper part of the formation in the most northerly wells in Jutland to range into or through the Sinemurian, whereas the top part in the centre of the basin is Rhaetian to early Hettangian in age. 


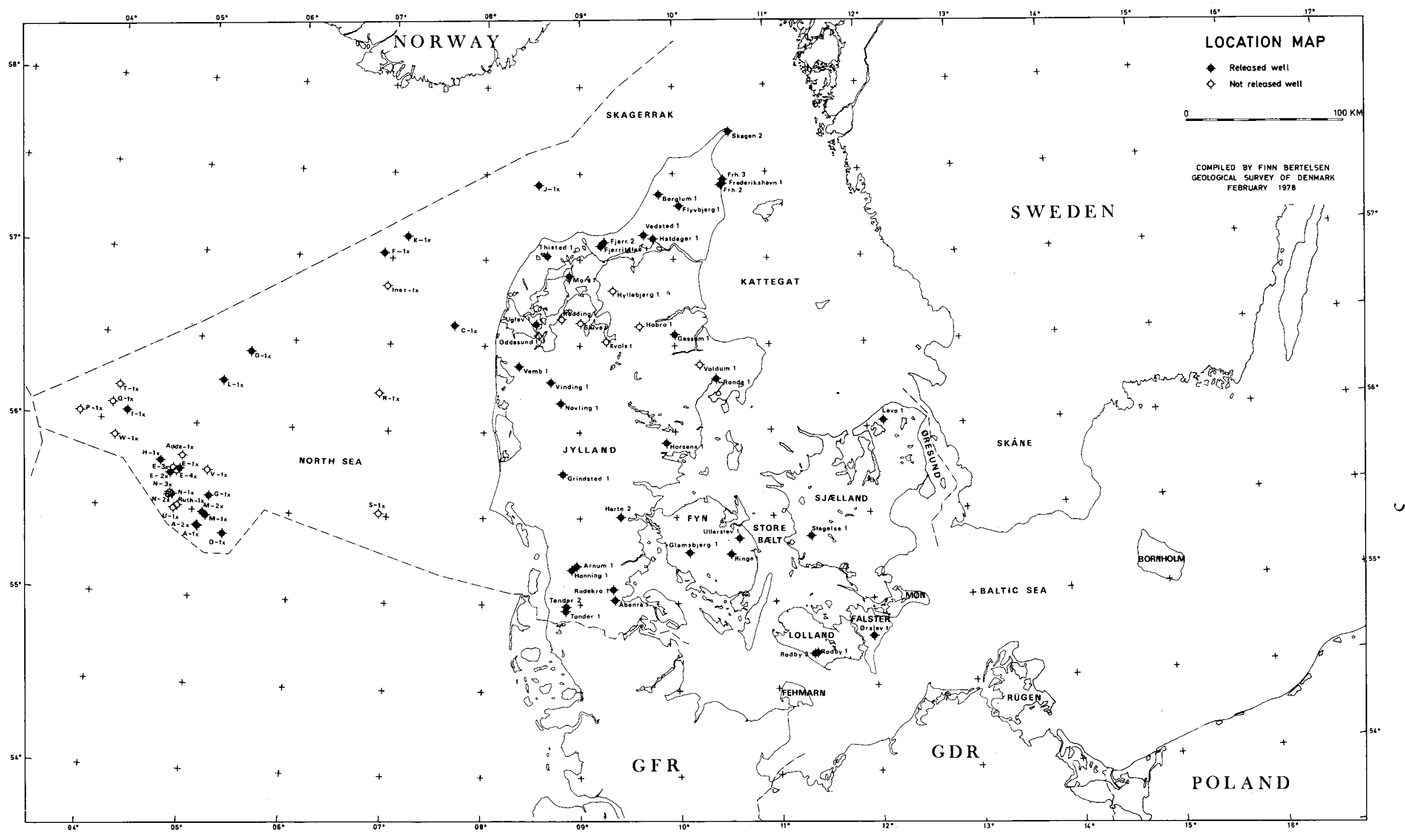

Fig. 1. Location map showing the position of deep Danish exploratory wells. »Released « means that the wells have passed a five year confidentiality period, after which data can be published by the Danish Geological Survey. 


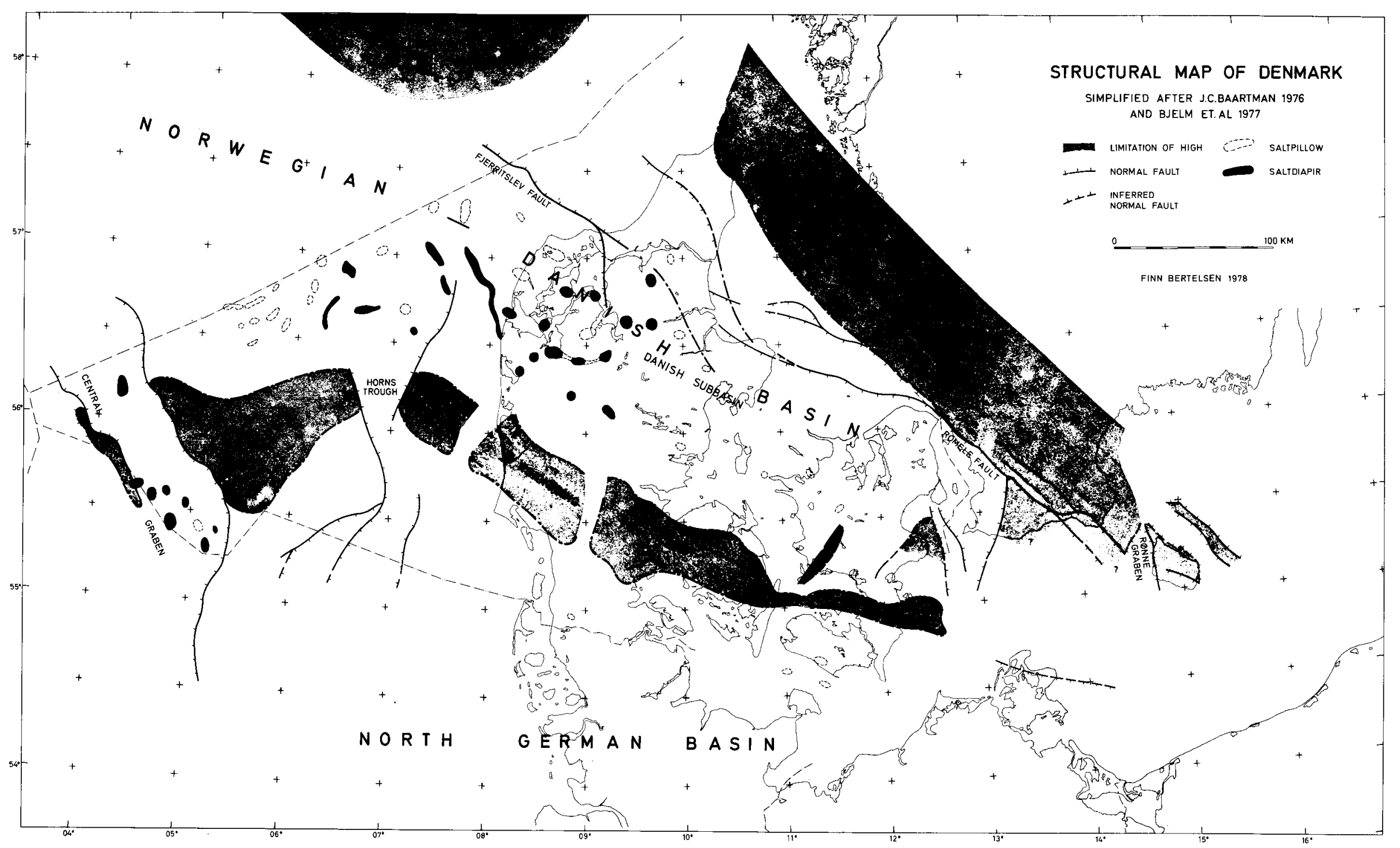

Fig. 2. Structural map of Denmark. Simplified after an unpublished map prepared by J.C. Baartman (D.G.U.) and adjusted in accordance with information given in Bjelm et al. (1977). 


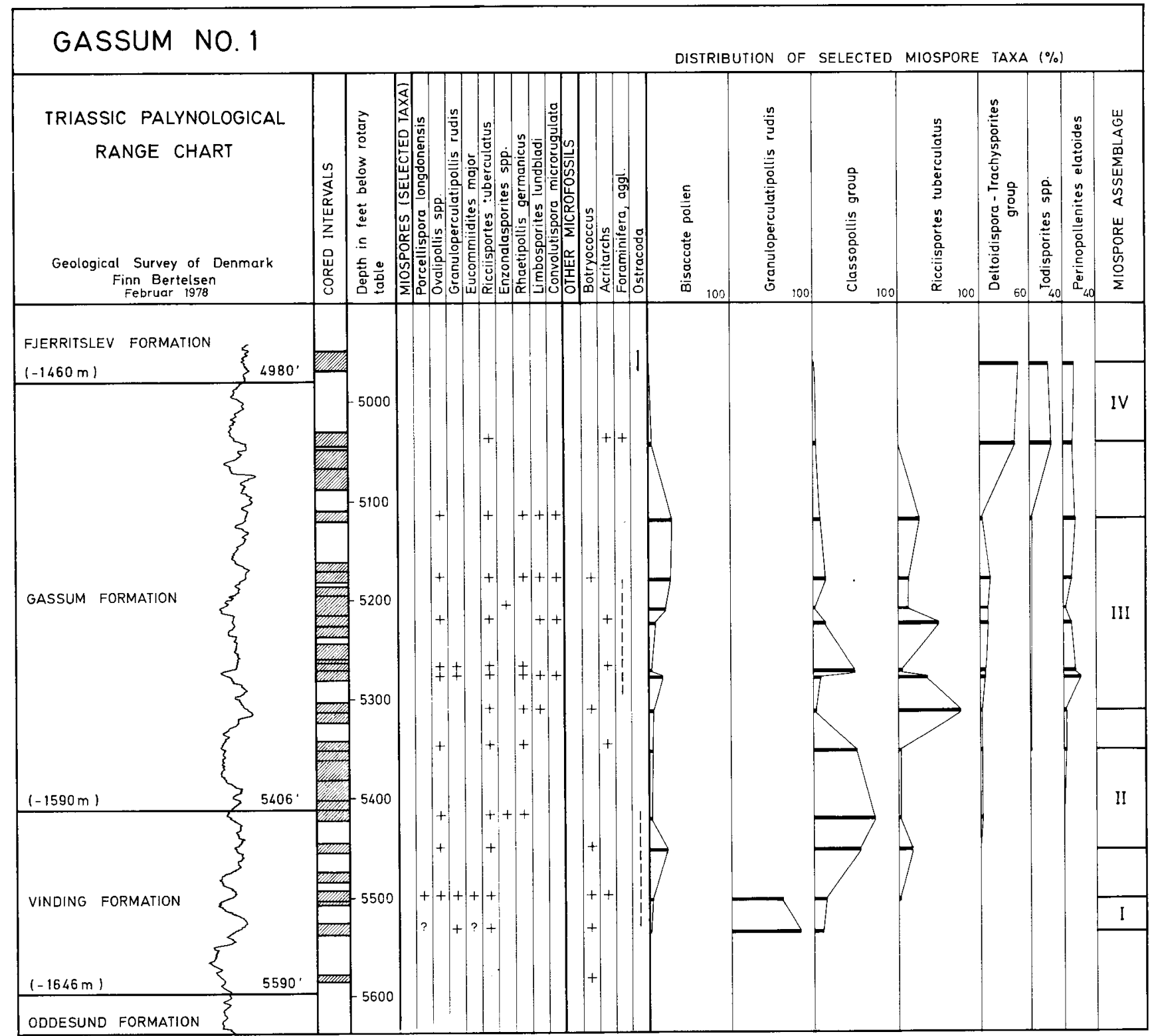

Fig. 3. Main characteristics of the palynological assemblages of the Vinding and Gassum Formations in the Gassum 1 well. The location of the well is seen in fig. 1. The core 4950-4970' contains a fauna of Hettangian age (Michelsen 1975) and assemblage IV is therefore of transitional Rhaetain/Hettangian age. Assemblage I-III indicates a Rhaetian age (cf. Lund 1977).

Palynology of the offshore Dansk Nordsø F-1 and $\mathrm{K}-1$ Triassic sections was included in a study by Bertelsen (1975), who recognized both formations in the $\mathrm{K}-1$ well, but only the Gassum Formation in the F-1 well. The palynofloras of the two wells were similar to those described from the late Triassic of England, Sweden, Poland and Germany.

Lund (1977) gave a comprehensive description of the Upper Triassic-Lower Jurassic palynofloras from wells of the North German Basin including the Danish Rødby 1 well, and samples from Skåne (Sweden). On the basis of his analyses and of literature studies, he was able to establish a regional miospore zonation for the eastern part of the North Sea Basin. This zonation seems to be applicable, with some modifications, to the Norwegian-Danish Ba$\sin$. This is of special importance for the stratigraphical breakdown of this basin, because miospores are the only fossils found in all of the recovered facies types.

A number of the vast group of papers dealing with various subjects of »Rhaeto-Liassic « geology in neighbouring countries is quoted in the description of the basinal development. Other sources used for the compilation of the maps may be found in the literature list.

It must be stressed that the term 'Rhaetic' is lithostratigraphic, whereas Rhaetian is a chronostratigraphical stage unit. 


\section{Vinding Formation (Larsen 1966) emend.}

Type section. Vinding No. 1 borehole, DGU File No. 76.94

$56^{\circ} 17^{\prime} 26^{\prime \prime} \mathrm{N}-08^{\circ} 41^{\prime} 56^{\prime \prime} \mathrm{E}$ of Greenwich

Depth interval (Larsen 1966)

$1523 \mathrm{~m}-1663 \mathrm{~m}$ below M.S.L.

Depth interval (proposed)

$1591 \mathrm{~m}-1648 \mathrm{~m}$ below M.S.L.

1652m-1710m below K.B. (Mud log + Drilling rate)

Thickness in type section: $58 \mathrm{~m}$

Reference section. Rønde No. 1 borehole, DGU File No. 80.164.

(fig. 4) $56^{\circ} 18^{\prime} 15^{\prime \prime} \mathrm{N}-10^{\circ} 26^{\prime} 07^{\prime \prime} \mathrm{E}$ of Greenwich

Depth interval (proposed)

2711m-2782m below M.S.L.

2753m-2825m below K.B. (Gamma RayNeutron 1:200)

Thickness in reference section: $72 \mathrm{~m}$

Original description. "At Vinding, in the south-western part of the basin, the Rhaetic is developed as dark to almost black clays about $180 \mathrm{~m}$ thick, in which subordinate, very thin sandstone bands occur. This development is clearly marine as shown by the content of both molluscs and microfossils. Very little is known about the geographical extent of this particular development. In the nearby boring Vemb 1 an evidently non-marine deposit has been attributed with some uncertainty to the Rhaetic, but since there are no cores from this well, the relation to the Vinding occurrence cannot be regarded as having been settled satisfactorily. Until now there has not been any definite information about Rhaetic occurrences in the salt dome area that separates Vinding from the localities Fjerritslev, Vedsted and Gassum. The isolated occurrence of marine Rhaetic at Vinding is called the Vinding Formation in the following account. It is possible that the clayey beds forming the base of the Gassum Formation in Horsens 1 and Gassum 1 should really be assigned to the Vinding Formation, but this question can only be settled after further, more detailed studies. «(Larsen 1966, p. 25).

\section{Remarks}

New information from several borings in the region (fig. 2) has revealed that the above-mentioned sug- gestion by Larsen is correct. The dark grey marine claystones in Vinding can be traced to Horsens 1 in the southeast, to Gassum 1 in the northeast, and as far as to the K-1 well in the North Sea (Bertelsen 1975). In the redefinition of the formation, however, the following facts must be pointed out. First, the presence of limestones in the formation has been found to be very typical (cf. Christensen 1972). This character is not mentioned in the description of Larsen although limestones are figured in the lithological column of the Vinding 1 well (Larsen, plate XI). Secondly, a comparison with the neighbouring Nøvling 1 borehole (as divided here - not as divided by Christensen, 1973) in the light of the new information seems to prove that the younger arenaceous Gassum Formation is included in the upper part of the type section of the Vinding Formation sensu Larsen. Third, no electrical logs have been run in the Vinding 1 borehole. For modern subsurface evaluation and correlation an adequately logged reference section is of major importance.

The Rønde 1 well is chosen as temporary reference section until a more feasible modern well is released. The interval in question was described by Christensen (1971) and Dinesen (1971). The shown lithological column has been revised by the present author. No cores were taken in Rønde 1, but in the nearby Gassum 1 well good cored sections are available in an almost identical lithological section of the formation. The results of the palynological investigation of the Gassum cores are shown in fig. 3.

\section{Redescription}

\section{Lateral extension and thickness}

The Vinding Formation is limited to the central part of the Danish Subbasin (map fig. 5). It extends out into the North Sea to the K-1 well (Bertelsen 1975), but is not yet reported from Norwegian waters. How far it extends towards the southeast along the axis of the basin is somewhat doubtful. The section from the Slagelse 1 well is atypically poor in carbonates - but is nevertheless included - and a mixed, more arenaceous facies is recovered in the Rødby and Ullerslev wells.

The thickness is typically between $\mathbf{4 0 - 9 0}$ meters. The releasable and revised well data are listed in table 1. 
RONDE 1

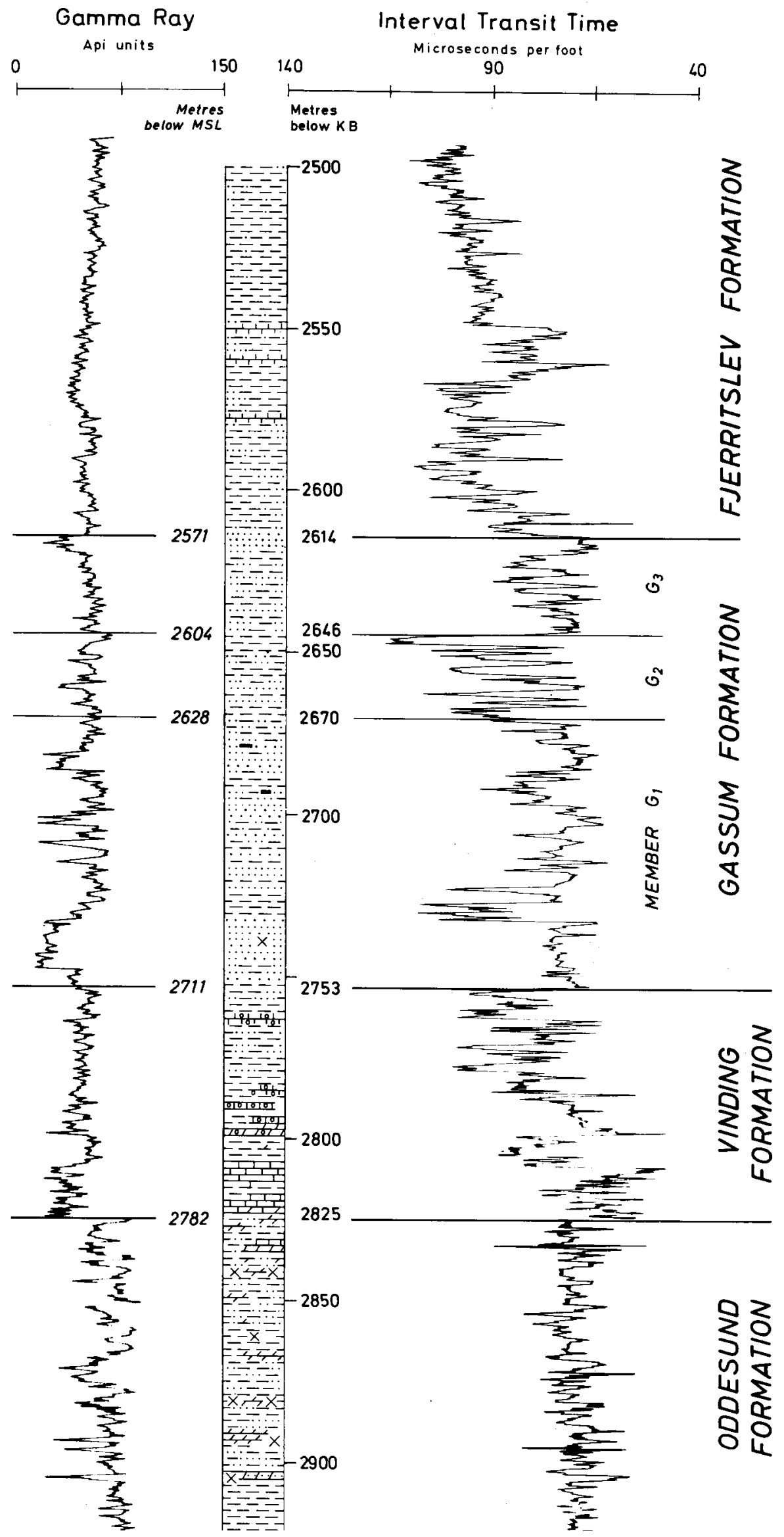

Fig. 4. Rønde 1. Reference sections of the Vinding and Gassum Formations. For Legend, see fig. 6. 


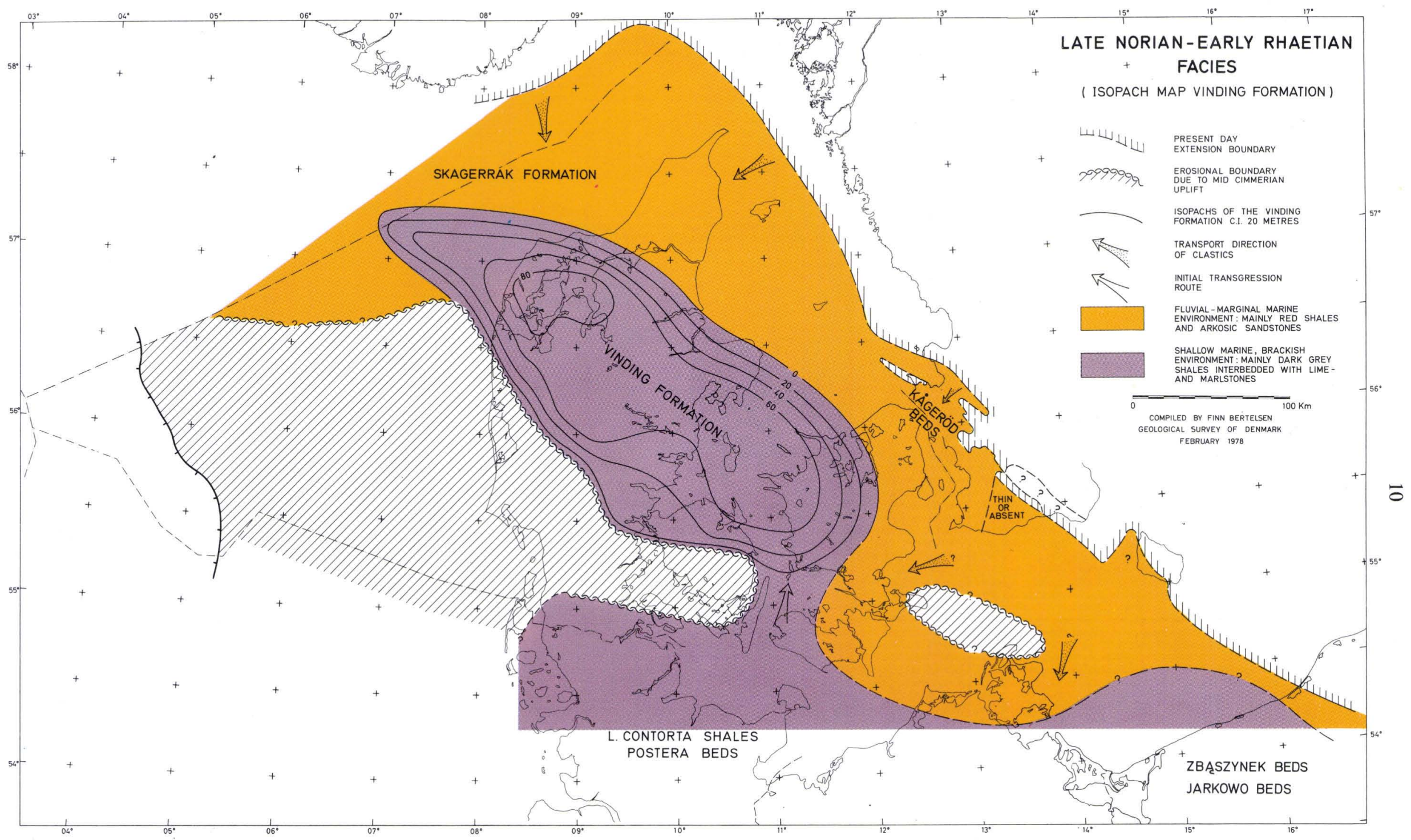

Fig. 5. Late Norian-early Rhaetian facies (isopach map Vinding Formation). Compiled from well data and sources mentioned in the selected bibliography. 


\section{Lithology}

The formation consists of interbedded claystones and limestones. The claystones are commonly laminated, with a varying silt content which generally increases in the upper part. Dark grey to black olivegrey colours are dominating, but brown and greenish shadings are sporadically encountered. The claystones are generally calcareous (dolomitic), pyriteand microlignite bearing. Anhydrite is sporadically present in the lower part. The limestones occur at rather constant levels and can be traced from well to well by means of wire line logs. The base of the formation is generally formed by grey and brown, microcrystalline dolomitic limestones. Greyish and brownish oolitic or pellet limestones are commonly developed in the middle part. In the upper part are found thin individual seams and bands of dolomitic limestones.

\section{Log motifs and boundary definitions}

The base of the formation can be traced from borehole to borehole by means of a gamma ray log, from which it is defined below a major negative peak of the basal dolomitic limestone. The rapid change of claystones and limestones is indicated by the many wide-ranging oscillations in the acoustic logs. The top of the formation is indirectly defined at the base of the basal sandstones of the constantly and conformably overlying Gassum Formation. It is most distinct in a CNL/FDC overlay log, by means of which possible limestone peaks in the gamma ray log are discernable from sand peaks (cf. Schlumberger 1974). In older wells with only limited wireline logs available, the top of the formation has been set by means of a gamma ray or S.P. log. In contrast to the beds of the basal Gassum Formation the claystones of the uppermost Vinding Formation frequently show caving, as seen from the caliper log.

\section{Geological age}

The age of the formation is late Norian-Rhaetian (cf. ostracod studies by O. Bruun Christensen and palynological analyses by the present author).

\section{Interpretation of the depositional history}

The deposition of the Vinding Formation took place in a shallow brackish marine sea, as evidenced by the presence of ostracod faunas of Darwinula and Limnocythere spp. and oolitic limestones (cf. Christensen 1962-1973 and Will 1969). It is judged from the distribution of the formation that the sea invaded the basin from the south, following the same route as the former Triassic Röt and Muschelkalk transgressions, i.e. through a depression situated in the present Storebælt area, for which the name the Storebælt Gate is proposed. The presence of almost identical ostracod faunas in the NW German Postera »Schichten « and the Vinding Formation (cp. Christensen 1962-1973) sustain this assumption. Also in NW Poland a similar facies, the Jarkowo Beds, is found (Senkowiczowa \& Szyperko-Sliwczyńska 1975, Dadlez 1976b, Kopik 1976). In marginal areas the Jarkow(o) Beds rest unconformably on eroded Carnian deposits.

During the initial transgression over the continental gypsiferous Carnian red beds (Oddesund Formation, in prep.) of the central basin, a phase with sabhka-type environments seems to have existed. The evidence is the basal facies of bedded dolomitic limestones, dolomitic and anhydritic claystones containing algal remains of Botryococcus. In the hinterland the sedimentation of low energy fluvial red beds continued, as seen in the Skagen 2 well, where the Upper Triassic fluvial, arkosic red beds have proved to contain a Granuloperculatipollis palynoflora (cp. fig. 3). The corresponding facies is known as the Kågeröd Beds in Skåne (Sweden) (Troedsson 1951) and constitutes the top Skagerrak Formation in the northwestern Norwegian-Danish Basin (Deegan \& Scull 1977).

With the establishment of more permanent water cover, ostracod faunas immigrated into the basin and the Ringkøbing-Fyn High became completely inundated. In the shallow environment were formed oolitic limestones and pelletal lime muds. A flora fringing the basin and producing Circumpollis-type pollen probably grew up at the same time. Similar type floras producing Classopollis pollen are found to be common in the tidal and deltaic deposits formed during the regressive Jurassic-Early Cretaceous phases, e.g. in the Wealden facies, but a distinctive, general relationship between the motherplants and the facies distribution can not at present be ruled out (cf. Batten 1976).

The deepening of the basin seems to have continued, but a gradual change in climate towards more humid conditions (cf. Will 1969) led to an increased influx of silt and fine-grained sand into the basin. This change is also seen in the composition of the microflora. The rather heavy Ricciisporites tetrads and much disseminated plant material dominate the palynopreparations visually, but the ClassopollisCorollina group is still common. Granuloperculatipollis almost disappears. At this stage the formation 
consists of the pro-delta claystones of a prograding delta - the Gassum Formation. This upper part of the Vinding Formation compares well with the "Untere Contorta Tone« of NW Germany (Will 1969).

In NW Poland the equivalent beds to the upper part of the Vinding Formation are the Zbaszynek Beds (cf. Dadlez 1976, Kopik 1976, Lund 1977).

\section{Gassum Formation (Larsen 1966) emend.}

Type section. Gassum No. 1 borehole, DGU File No. 58.231

$56^{\circ} 33^{\prime} 76^{\prime \prime} \mathrm{N}-10^{\circ} 00^{\prime} 18^{\prime \prime} \mathrm{E}$ of Greenwich

Depth interval (Larsen 1966):

$1513 \mathrm{~m}-1642 \mathrm{~m}$ below ground (ground elevation $53.3 \mathrm{~m}$ )

Depth interval (proposed):

$1513 \mathrm{~m}-1643 \mathrm{~m}$ below ground level.

Thickness in type section: $130 \mathrm{~m}\left(426^{\prime}\right)$

Reference sections

Basin center: Rønde No. 1 borehole, DGU File No. 80.164

(fig. 4) Depth interval (proposed):

$2571 \mathrm{~m}-2711 \mathrm{~m}$ below M.S.L.

2614-2753m below K.B. (Gamma Ray-

Neutron 1:200)

Thickness in reference section: $139 \mathrm{~m}$

(fig. 6) Basin margin: Flyvbjerg No. 1 borehole, DGU File No. 9.317

Depth interval (proposed):

$1261 \mathrm{~m}-1457 \mathrm{~m}$ below M.S.L.

1308m-1504m below K.B. (S.P.-Resistivity

$1: 1000)$

Thickness in reference section: $196 \mathrm{~m}$

Original description. "The Gassum Formation is a predominantly light grey to whitish, in places rather coarse-grained sandstone, sometimes resembling an arkose, with subordinate dark-coloured clay bands and coal lenses; fragments of coalified wood together with remains of leaves etc. appear here and there. In a few places a sparse microfossil content is found. Where sand and clay alternate in thin beds, lenticular and crumpled bedding can be seen now and then; since the deformed zones appear to be bounded by ob- viously undisturbed layers, the deformation may be classified as synsedimentary, probably belonging to the phenomena slumping $\left(\right.$ see $\left.^{* *}\right)$. In a few cores there are vertical, straight, sand-filled tubes, some of which may be due to burrowing mussels, while others are obviously the work of worms (see **). The lithology, extent and form of the formation suggest that it is of deltaic origin and spread out into the basin from a source in the north or northeast«. (Larsen 1966, pp. 23-24).

\section{Remarks}

The Gassum borehole is regarded as the type locality for the Gassum Formation, although this is not formally established. The formation is only said to be named after this borehole (Larsen 1966, p. 23).

The top of the formation in the Gassum borehole is at $1513 \mathrm{~m}$ below ground level, as seen in plate XII of Larsen. This corresponds to the depth $4980^{\prime}$ below the rotary table. The reason for the selection of this special depth is probably to be found in a remark by A. Nørvang in a DAPCo report of August 6, 1948:

»Increased hardness of the rock below $4980^{\prime}$ is reported in the Geologist's Log and this depth is for that reason chosen as the top of the Rhaetic «. Later on, this depth was figured as the top of the Rhaetic by Sorgenfrei \& Buch (1964). This boundary also coincides with the top of a minor arenaceous bed, however, to judge from the gamma ray curve, which shows a distinct minimum below ca. 4980'. By use of the gamma ray curves this level can be correlated to the Voldum 1 and Rønde 1 borings southeast of Gassum, where it corresponds to levels with low average velocities above and high average velocities below as seen from the sonic $\log$. As the sonic $\log$ has been selected in later work as one of the basic curves for determination of the top of the Gassum Formation the original top depth in the Gassum boring has remained unaltered.

The base of the formation in the Gassum borehole fortunately occurs in a cored section with $100 \%$ recovery. It is to be defined as the transition point from the barren sands above to the underlying claystones of the Vinding Formation (see later) at a depth of 5406' below rotary table. The recognition of this level in other borings will be discussed later under ' $L o g$ motifs'. Relevant critical remarks on the lithostratigraphical treatment of the Gassum Formation in Deegan \& Scull (1977) are given in Michelsen (1977) and thus no further comments are needed. 
FLYVBJERG 1

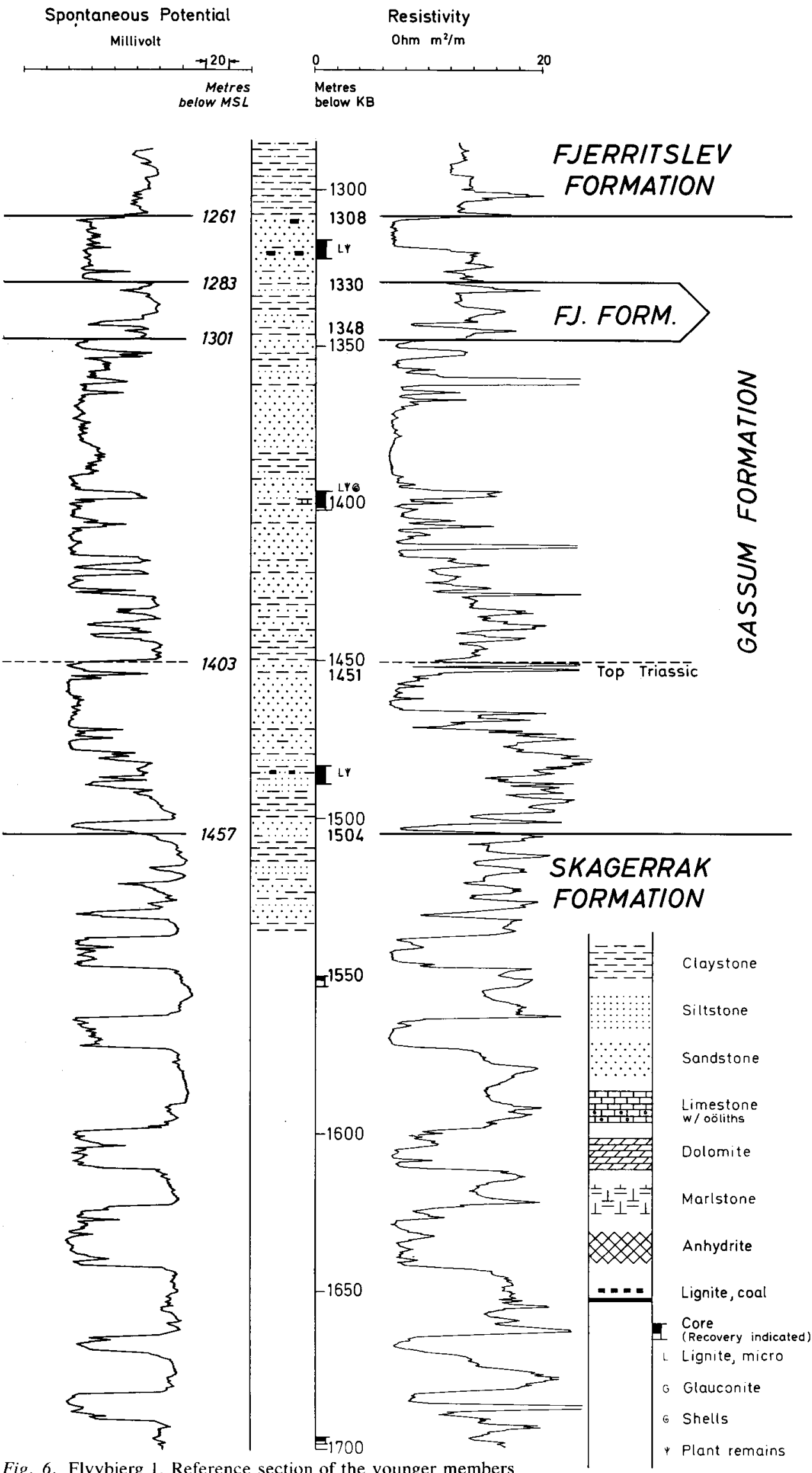

Fig. 6. Flyvbjerg 1. Reference section of the younger members of the Gassum Formation. See also fig. 8. 


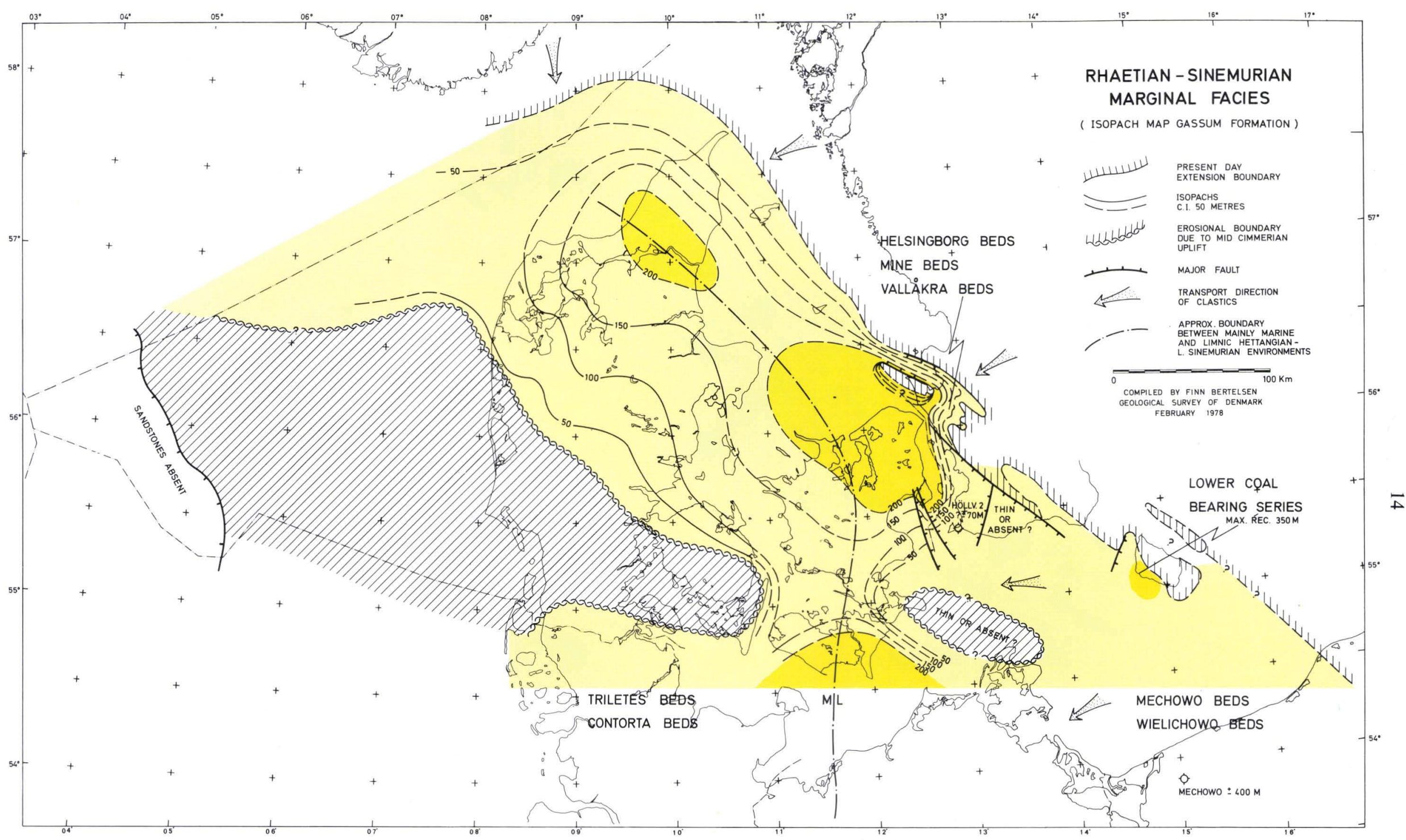

Fig. 7. Rhaetian-Sinemurian marginal facies (isopach map Gassum Formation). Compiled from well data and sources mentioned in the selected bibliography. 
LOG MOTIFS OF THE VINDING AND GASSUM FORMATIONS IN THE DANISH SUBBASIN

SW-NE CROSS-SECTION

$$
\begin{aligned}
& \text { GEDLOCGCAL SUNVEY OF DENMARK } \\
& \text { I976 FINN EERRELLEN }
\end{aligned}
$$

VEMB 1

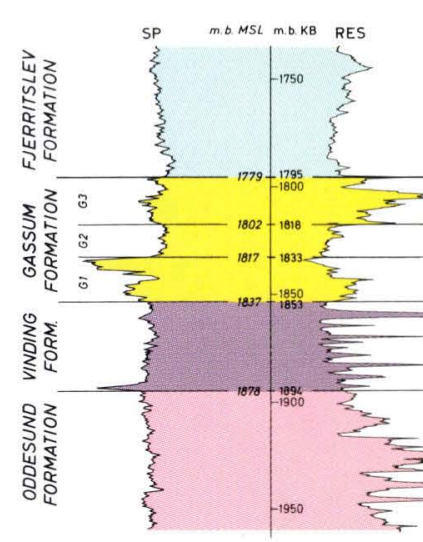

THISTED
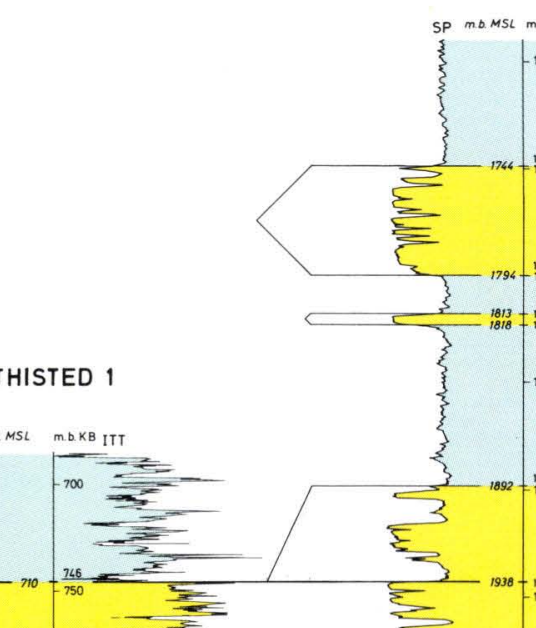

VEDSTED

MEMSL MOKB PES
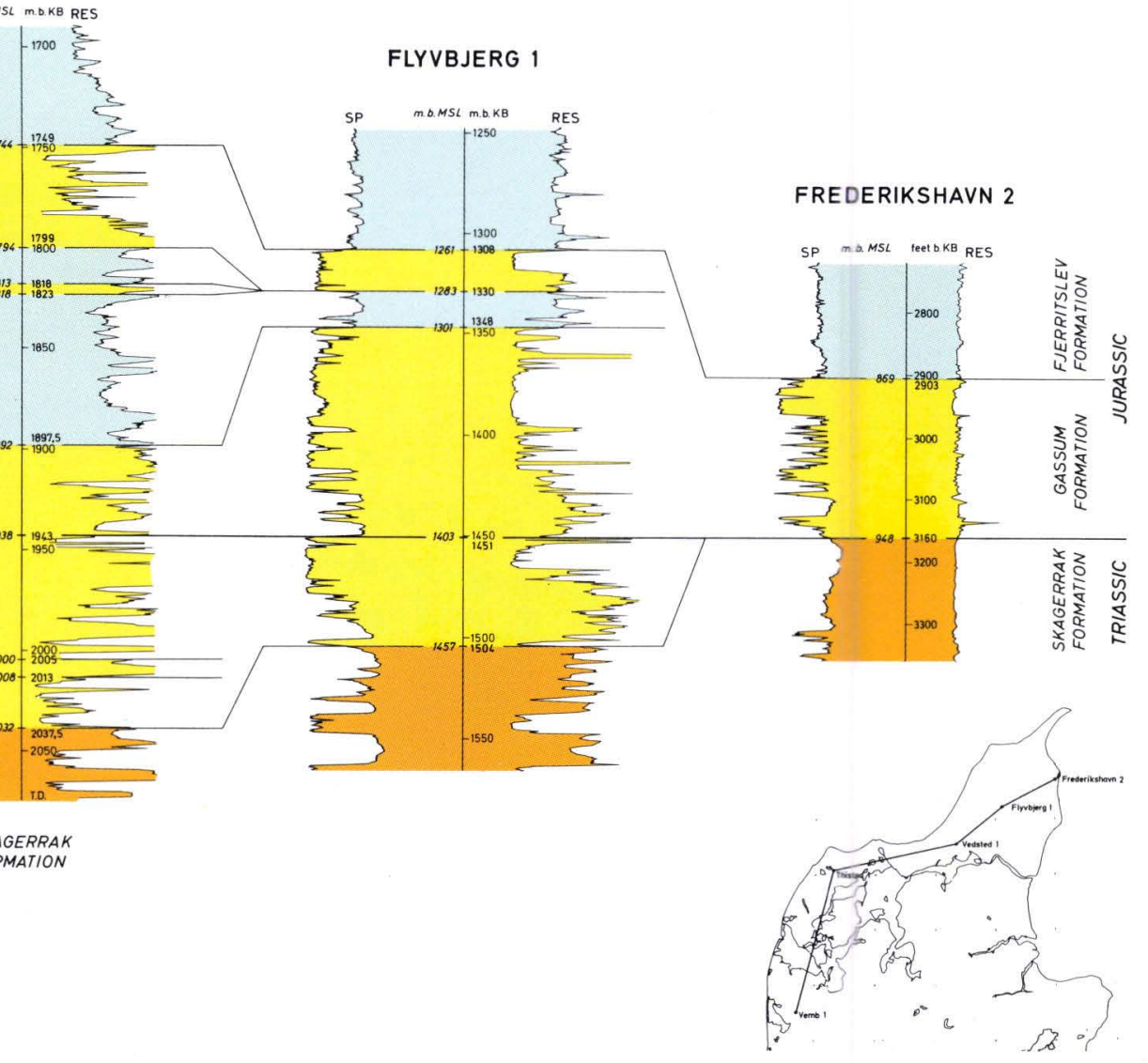


\section{Redescription}

\section{Lateral extension and thickness}

The sediments of the Gassum Formation are recognized in borings north of the Ringkøbing-Fyn High (fig. 7). To the northwest the formation extends out in the North Sea, being present in the wells Dansk Nords $\emptyset$ F-1, K-1 and J-1 (Bertelsen 1975, Michelsen 1978). It is also known to be present in Norwegian borings further to the northwest in the NorwegianDanish Basin (Deegan \& Scull 1977, Michelsen 1978). It is still uncertain how far the formation extends in an easterly and southeasterly direction (see Larsen 1966 , p. 28), but the wells Ullerslev 1 , Rødby $1 \& 2$, and Ørslev 1 are included in the present study. The coal bearing Rhaetian sands of Skåne, however, are obviously comparable with the Gassum Formation. In a seismological study of the Kattegat area, Baartman found that: "The second most continuous seismic event is associated with the approximate top of the Triassic formation. This horizon provides a strong reflector throughout most of the western and southern portions of the Kattegat area, when not disturbed by faulting. Subsurface control at the Rønde No. 1 and Gassum No. 1 wells indicates that this horizon corresponds approximately with the Rhaetic formation: a marine and deltaic deposition in this area, which in N. Jylland and the Kattegat is developed as a predominantly sandy facies. " (Baartman \& Christensen 1975, p. 10).

The revised thickness measured in the individual wells are figured in table 2 .

\section{Lithology}

Three members are generally recognized in the central and southern part of the basin. The lower $G_{1}$ Member contains the main reservoir beds of this area. It is typically developed as an upwardly coarsening unit, starting with interbedded dark grey claystone, siltstones and fine-grained sandstones, finely laminated, carbonaceous, micaceous and slightly pyritic. The upper beds consist of fine- to medium-grained, sometimes coarse-grained quartzose sandstones, whitish, olive-grey and greenish-grey, locally with thin coal seams. In the southeastern area, including wells such as Gassum 1, Rønde 1, Horsens 1, Slagelse 1 and Ullerslev 1, it has a more abrupt base towards the Vinding Formation, and the upper part is more clayey.

The $G_{2}$ Member is characterized by the dominance of black to olive-grey, carbonaceous claystones over minor siltstone and fine-grained sandstones.

$\mathrm{G}_{2}$ grades upwards into the lighter coloured grey and red-brown silty claystones of the $\mathrm{G}_{3}$ Member, followed by mainly fine-grained sandstones and siltstones, light greenish-grey, micaceous, commonly glauconitic and minor claystones, grey, greyishbrown and greenish-grey.

The tripartion of the formation described above is confined to the central and southern part of the basin. Towards the north (that is inclusive of the Mors 1 well) the formation is represented by still younger sandy members sometimes seen to be interdigitating with the marine, dark grey claystones of the Lower Jurassic Fjerritslev Formation. There seems to be a general coarsening of the sediments towards the north and the oldest cycles drilled in the VedstedFlyvbjerg-Børglum area have a distinctive cyclical nature with crossbedded upwardly fining sequences. Coal beds occur sporadically. For further lithological details see Larsen 1966 (pls. III, IV, V, VII), but note that the chronostratigraphy given is not fully valid.

\section{Log motifs and boundary definitions}

The formation in its entirety, as well as the individual members, is defined on the interval transit time log in combination with the gamma ray, S.P. and compensated neutron-formation density (overlay) log. The caliper log may also be useful because the claystones cave into the borehole, in contradiction to the porous sandstones. The very micaceous, glauconitic sandstones of the $\mathrm{G}_{3}$ Member may cause difficulty for a definition of the boundary based on the gamma ray-interval transit time log. But the problems can be solved by the use of the compensated neutronformation density (CNL/FDC) overlay technique (Schlumberger 1974) in combination with the caliper log. As previously mentioned, the overlay technique is also useful for the lower demarcation towards the Vinding Formation.

A variety of log motifs in the gamma ray and S.P. logs are seen within the various sandy members, depending on the situation of the wells within the basin (see fig. 8 and plates in Larsen 1966). Upwardly coarsening sequences (funnel-shaped log motifs if the $\log$ is rotated around its own axis) are typically seen in the $G_{1}$ Member in the southern and central part of the basin. Towards the north and east they grade into cylindrical motifs (more constant grain size). Bell-shaped motifs (upwardly fining) sequences are sometimes noted in the top of $\mathrm{G}_{1}$. 


\section{Geological age}

The Gassum Formation is diachronous (cp. fig. 8). In the basin center it is of mainly Rhaetian age with miospore assemblages of type II-III (cp. fig. 3; Lund 1977), but with the upper part (ass. IV) transitional to Hettangian. To the north the younger members are of Hettangian-Sinemurian age.

\section{Interpretation of the depositional history}

In accordance with Larsen (1966) the Gassum Formation is interpreted as a mainly fluvio-deltaic deposit. With the aid of log motifs, sediment characters, and fossil content, and following the analytical interpretation system of Selley (1975) the depositional history may be outlined as below.

The log motifs of the gamma ray or S.P. logs of the lowermost member, the $\mathrm{G}_{1}$ sandy member show generally upward coarsening sequences in the basin center. The »nervous « characters of the logs and information from sidewall cores demonstrate a laminated sequence grading from interbedded clay/ siltstone below towards fine-, middle- and even coarse-grained sand above. All sediments contain dispersed carbonaceous material, lack glauconite and are generally barren with regard to marine microfossils such as ostracods and foraminifera. Sometimes a basal thin glauconite bearing sandstone is present. The top part of the member is defined by a more or less gradual change to clay deposition. Occasional coal seams are present near the top of the member and some thin dolomitic bands may also be found.

The $\mathrm{G}_{1}$ Member is interpreted as the deposits of a northern so-called Gassum Delta (Larsen 1966). Deltafront upwardly coarsening sequences are found in the southern and central part of the basin. The facies is grading into distributary channel sands towards the top of the member with upwardly fining lithology sometimes ending up in interdistributary bay coal-swamp deposition (Mors 1, Dansk Nords $\varnothing$ $\mathrm{K}-1$ ). The corresponding fluvial hinterland deposits have not yet been located definitely, but the Vallåkra Beds in Skåne may be a representative facies. The thin occasionally recognized basal glauconitic sandstone may be interpreted as a submarine channel deposit.

The mainly clayey distal $\mathrm{G}_{2}$ Member is palaeontologically characterized by the incoming of a sparse fauna of Ammodiscus agglutinating foraminifera and Rhaetavicula contorta (Portlock) bivalves (the latter recorded in Vinding 1 and Gassum 1), whereas no important change is noted in the palynoflora (cp. fig.
3). The deposits are interpreted as the sediments of a drowning delta-plain, probably due to a eustatic rise in sea level and/or an increased subsidence rate. Self-compaction may also explain the drowning.

The dark-coloured clays are generally rich in disseminated plant material and pyrite which points towards anaerobic floor conditions. The $G_{1}$ and $G_{2}$ members are correlated with the middle and upper Contorta Beds (»Hauptsandstein « and $»$ Obere Contorta Tone «) of NW Germany (Will 1969) and with the Vallåkra and Mine Beds of NW Skåne (Sweden) (Troedsson 1951). In the Polish Lowlands the $\mathrm{G}_{1}-\mathrm{G}_{3}$ Gassum Formation equivalent can be proven by palynology to be the Wielichowo Beds (cp. fig. 3; Lund 1977 and lithology by Kopik 1976).

The subsequent $\mathrm{G}_{3}$ Member, corresponding in NW Germany to the Triletes Beds (»Ober Rhaet Sandstein «) (Will 1969), seems to represent a regressive phase - a final pulse of the Early Cimmerian phase during which limnic conditions returned to the basin. The dark grey claystones of the $\mathrm{G}_{2}$ Member grade upwards into the partly red-coloured silty claystones (»Rote Levalloische Tone « cf. Will 1969) of the $\mathrm{G}_{3}$ Member, which may mean that the anaerobic environment of $\mathrm{G}_{2}$ was replaced by an oxidizing milieu. The clayey deposits grade towards the north into more sandy deposits. They are overlain in the basin center by fine-grained sandstones, siltstones and shales, light coloured, calcareous, micaceous and glauconitic, which may represent mouth bar deposits or shoal sands formed in front of a regressive delta withdrawing northwards during the early Jurassic transgressive phase.

There are several indications besides the abovementioned ones for a regressive and tectonically active stage between the time of deposition of the $\mathrm{G}_{2}$ ("Contorta $\ll$ ) shales and the Lower Jurassic shales of the Fjerritslev Formation. As pointed out by Troedsson (1951), in NW Skåne (Sweden) there is a break in the sedimentation between the coal-bearing beds of the Mine Beds and the overlying Boserup Beds, which constitute the basal member of the Hettangian Helsingborg Beds, and which were found by the present author to contain megaspores of Nathorstisporites hopliticus Jung. The basal Boserup Beds are kaolinitic, sometimes developed as weathered arkoses, sometimes as pure clay, and they may either overlie the Mine Beds abruptly or onlap the Archaic basement. Lund (1977) correspondingly concluded on the basis of palynological investigations that the Upper Rhaetic is probably missing both in NW Poland and in Skåne. The synsedimentary tectonic activity during the deposition of the Vallakkra and Mine Beds is discussed and exemplified by Bölau (1969). 
In the Pomerania Trough of NW Poland an unconformity is widely recognized at the base of the Jurassic (Dadlez 1976b).

It should also be mentioned that no Rhaetian aged deposits are known from the island of Bornholm, situated in the Fennoscandian Border Zone of the Baltic Sea. According to Gry (1969) the Hettangian to Lower Sinemurian ( $N$. hopliticus bearing) Lower Coal Bearing Series rests unconformably on either Archaic basement or Keuper red beds, thus testifying to drastic tectonic events analogous with those described from the FBZ in Skåne. Finally, attention must be drawn to the missing Middle-Upper Rhaetic sequence in the Skagen 2 well, as proven by the present investigation.

The final phase in the development of the Gassum Formation comprises the Hettangian-early Sinemurian time interval. The basin was transgressed by a shallow sea, which was inhabited by a variegated marine fauna of foraminifers, ostracods, lamellibranchs and cephalopods, and which gave rise to the basinal claystones of the Fjerritslev Formation (Sorgenfrei \& Buch 1964, Michelsen 1975-1978). In the northern, eastern and southeastern margins the deposition of sands in deltaic, now more tidally influenced environments continued (cf. Sellwood 1972). These sands constitute the youngest members of the Gassum Formation. In northern Jylland they interdigitate with the Fjerritslev Formation as seen in the S.P. logs from Flyvbjerg 1 and Børglum 1 (see fig. 8 and pls. in Larsen 1966). Palynological investigations (to be published separately) have shown that the main part of the formation in this area is of HettangianLower Sinemurian age. However, it should be mentioned that three different megaspore assemblages are recorded: the $T$. pinguis ass. (Rhaetian), the $N$. hopliticus ass. (Hettangian-L. Sinemurian) and the $H$. planatus ass. (U. Sinemurian). The latter assemblage is not restricted to the U. Sinemurian, but ranges up through the Domerian (cf. Marcinkiewicz 1971). The marine, ostracod-bearing claystones of the Fjerritslev Formation overlying the Gassum Formation in this region are however of Sinemurian-L. Pliensbachian age (Michelsen 1975), which gives the Gassum Formation an upper age limit. Contemporaneous beds are found in NW Skåne (Helsingborg Beds, Troedsson 1951), as mentioned earlier. According to Vossmerbäumer 1970 they belong to a deltaic complex which was gradually growing and becoming submerged. A similar fluvially and tidally influenced facies regime is also found in the southeastern Danish area (Sellwood 1972, Michelsen 1973). It is part of a major fluvio-deltaic complex occupying the Polish Basin and the eastern part of the
North German Basin (Will 1969, Dadlez \& Kopik 1970, Häusser \& Kurze 1975). Control points with recovery of $N$. hopliticus assemblages are the Swedish Höllviken 2 and Svedala wells (Brotzen 1950, Lundblad 1956), the Rødby 1 and Ørslev 1 wells (Bertelsen \& Michelsen 1970, Michelsen 1975) and the Lower Goal Bearing Series of Bornholm (Gry 1969). Reference must also be made to the megaspore studies by Marcinkiewicz (1971) of the contemporaneous Polish Mechowo Beds.

Fully marine environments were established throughout the Danish Subbasin during Lower Sinemurian. The Lower Sinemurian Döshult Beds of Skåne (Troedsson 1951) represent the sandy, nearshore deposits of the transgression. They differ mainly from the underlying Helsingborg Beds in that they contain a fauna of purely marine fossils such as ammonites, belemnites and brachiopods.

At the same time a major transgression took place from the west into the East German part of the North German Basin (Schumacher \& Sonntag 1964). In the Polish Lowlands the main transgression took place in early Pliensbachian (Dadlez 1976b). The Pomerania Trough situated along the Precambrian Platform was only slightly affected by the transgression (Dadlez 1976b). Minor, earlier ingressions of the sea are however seen in the Lower and Upper Mechowo Beds cp. fig. 9 (Dadlez 1976a), but due to lack of fossil evidence the dating of those events is somewhat doubtful.

The marine series overlying the Lower Coal Bearing series on Bornholm have been dated to L. Pliensbachian by means of ammonites (Gry 1969).

\section{»Ullerslev Formation «}

The sandstones of the Gassum Formation in the central and northwestern part of the Danish Subbasin were undoubtedly transported into the basin by rivers coming from the north and northeast as originally stated by Larsen (1966) and as seen in the outcrops in Skåne (Troedsson 1951, Bölau 1969). More doubtful is the origin of the sandy sediments recovered in the Ullerslev 1, Rødby $1 \& 2$ (and later the Ørslev 1) wells which were named the Ullerslev Formation by Larsen. Larsen considered the Ullerslev Formation to be contemporaneous with the Gassum Formation and regarded it as a local deltaic complex fringing the Ringkøbing-Fyn High and originating from »the Ringkøbing-Fyn island « (Larsen 1966, p. 88). Lar- 
sen's concepts with regard to the Ullerslev Formation are now doubted however in the light of the newer information from the region. Firstly, the palynological investigations of the Rødby 1 well by Lund (1977) have shown that the lower part of the Ullerslev Formation in this well corresponds to the German Postera Beds (sensu Will 1969). This means that this section was deposited simultaneously with the Vinding Formation as re-defined in the present paper. Secondly, also the lower but not so arenaceous part of the section in the Ullerslev well is contemporaneous with the Postera Beds as proven by the ostracod fauna (Christensen 1962) and this limestone-bearing section too has therefore been regarded as a marginal deposit of the Vinding Formation (cf. well data, table 1). Thirdly, there is a striking similarity between the lithology and log motifs of the remaining upper sandy part of the Ullerslev well section and the Gassum Formation sections of the Horsens 1, Rønde 1, Gassum 1, Slagelse 1 and other wells, and thus this part has been included in the Gassum Formation.

The heavy mineral associations of the Rødby 1 and Ullerslev 1 deviate from those of the Gassum Formation in northern and central Jylland etc. in having a low garnet and a high tourmaline content, as stressed by Larsen. The main basal sands of the two wells here regarded as belonging to the Gassum Formation are further seen to be rather quartzose (high quartz/ feldspar ratio) (Larsen 1966, pls. XIV, XV). The sands are thus very close in composition to the uniformly composed Rhaetian-Hettangian sands recovered in the northern part of the G.D.R. (D.D.R.) (Häusser \& Kurze 1975). These sands have been shown by the aid of heavy mineral spectra and grain size studies to have come from the Baltic area in a southwesterly direction (so-called »BaltischOstmecklenburgische Schüttung « by Kurze). It is therefore assumed that the Rhaetian and Hettangian-L. Sinemurian sands in the southeastern Danish region originate from the Baltic drainage system, too. This also explains why the Rhaetian and Hettangian are distinctly more arenaceous in the Ørslev 1 well than in the Rødby 1 well, which is situated more westerly, and why thick Hettangian-Lower Sinemurian deposits are present on Bornholm - although the importance of local border zone tectonics must not be forgotten.

As a conclusion to the above discussion it has been decided to repeal the Ullerslev Formation as a lithostratigraphical unit. In the type section, the Ullerslev well, it is to be divided into and be replaced by the Vinding Formation and the Gassum Formation (cf. tables 1 \& 2). With regard to the Rødby and Ørslev wells more investigations are probably needed before a formal lithostratigraphy for those wells can be finally established.

Michelsen (1973) has shown that the Lower Jurassic section in Rødby 1 is composed of alternating intervals of terrestial and marine dominance, whereas the corresponding section in Ørslev 1 (Michelsen 1975) can be divided into a lower deltaic type deposit with megaspores of the $N$. hopliticus assemblage and barren of ostracods, and an upper marine, ostracod-bearing section referable to the Fjerritslev Formation. Michelsen (1975) provisionally included the entire Lower Jurassic sections in both wells into the Fjerritslev Formation.

In the present paper, the entire Lower Jurassic section of the Rødby wells is included in the Gassum Formation and the marine intervals are regarded as interdigitating stringers of the Fjerritslev Formation as seen in the northern margin of the basin. In the $\emptyset$ rslev well the above-mentioned lower section of the Lower Jurassic interval is included in the Gassum Formation, whereas the upper section is referred to the Fjerritslev Formation.

\section{Postsedimentary erosion}

The rôle of the Ringk øbing-Fyn High as a depositional barrier between the North German Basin and the Norwegian-Danish Basin which came into function during the Permo-Triassic had had its day by the late Triassic. This means that the Ringkøbing Fyn High is assumed to have become completely inundated during the main part of the time span covering the deposition of the Vinding and Gassum formations. This thesis, which is contrary to the opinion of earlier writers, is based on the following considerations. 1) There is a striking similarity in the facies and faunal distribution on both sides of the High (Will 1969, present description). In NW Germany the change towards more basinal (marine) deposits - the fining direction - is from $\mathrm{E}$ to $\mathrm{W}$, which is more or less parallel to the direction of the Ringkøbing-Fyn High. In the Danish Subbasin the general fining direction is from NE towards SW. 2) Michelsen (1977) in discussing the distribution of the Lower Jurassic Fjerritslev Formation reached analogous conclusions with regard to the original extension of the lower Jurassic sea. Neither lithological nor biological indications of near-shore conditions are found along the northern flank of the Ringkøbing-Fyn High or in the Central Graben; thus the Ringkøbing-Fyn High hardly could be regarded as a source area. He further claims that the tectonic activity at the Lower/Middle Jurassic transition may have led to erosion of the Lower 
Jurassic sequence along the RFH to the southeast (Sjælland) and probably also to the northwest in the Norwegian part of the Norwegian-Danish Basin. 3) If the RFH was exposed during the Rhaetian (formed an island cf. Larsen 1966) it is difficult to explain the presence of almost complete Keuper sequences in such wells as Ringe 1 (Fyn), Grindsted 1 (Jylland) and Dansk Nordsø $\mathrm{C}-1, \mathrm{R}-1$ and $\mathrm{S}-1$, and the recovery of the Vinding Formation so far south as in the Harte 2 well (Jylland) in »normal « basinal development. It is therefore concluded that the two basins, the North German Basin and the Danish Subbasin were directly connected and were part of one major depositional province (cf. Will 1969). The most obvious explanation for the inundation of the RFH is a relative rise of the sea level due to global eustatic changes (Vail et al. 1977). The pronounced hiatus (cp. fig. 7) over the RFH and including the Møn-Arkona High with surrounding areas covering the late Triassic-late Jurassic/early Cretaceous time interval indicates a general uplift of the central North Sea area sometime during the Jurassic. According to Ziegler (1977), Michelsen (1977), and others, this uplift took place by the end of the Lower Jurassic during the so-called Mid-Cimmerian Phase. During the subsequent period rapid subsidence of the Central Graben took place and much of the graben fill is believed to originate from eroded Rhaetian and Lower Jurassic sediments, as evidenced by the presence of e.g. Rhaetian re-worked Ricciisporites pollen throughout the Middle-Upper Jurassic Central Graben sequence. At the same time the RFH reappeared as a depositional barrier between the North German and the Norwegian-Danish Basin.

Increased tectonic activity in the block-faulted Fennoscandian Border Zone accompanied by vulcanism occurred simultaneously during the MiddleUpper Jurassic, as seen in Skane. The present-day distribution of the discussed sediments in e.g. Skåne and Bornholm is however a function of late Cretaceous-early Tertiary Laramide »inversion « movements (Ziegler 1977) during which the Shield margin NE of the Fjerritslev-Romele Ås fault trend (cp. fig. 2) was uplifted - and of subsequent erosion during the Pleistocene glaciation.

\section{Summary of the depositional history}

The deposition of the Vinding and Gassum formations took place at the Triassic-Jurassic transition. The mainly continental Triassic regime was replaced by a marine regime dominated by shallow water, epeiric seas. The depositional story reflects the interaction of the two major controlling factors, the climate and the eustatic change in sea level due to crustal tectonic events. Parts of this story are schematically summarized in fig. 9 , which shows the cyclical development of the sedimentation.

The first cycle comprises the deposition of the Vinding Formation and the basal $\mathrm{G}_{1}$ Member of the Gassum Formation. After an initial regressive phase (Early Cimmerian), which is recognized as a break in sedimentation in Poland and the G.D.R., a shallow brackish sea invaded the Danish Subbasin, the North German Basin and the Polish Basin, giving rise to the sedimentation of the Vinding Formation and equivalent lime-rich, clayey formations. The RingkøbingFyn High gradually became inundated and faunal connection between the basins was established. In the northern and eastern marginal areas the sedimentation of red beds continued (the Skagerrak Formation and the Kågeröd Beds). A gradual change in climate towards more humid conditions in combination with a minor regression caused the $G_{1}$ fluvio-deltaic sands to spread into the basin and thereby brought the first cycle to an end.

The second cycle is initiated by the invasion of the »Contorta Sea « due to increased subsidence of the basin floor or rather to a relative rise in sea level. The $\mathrm{G}_{1}$ delta complex was drowned and covered by the muds of the $\mathrm{G}_{2}$ Member. A renewed uplift, during which the margins became positive (or a lowering of the sea level) finished the second cycle. A deposition of sands ( $\mathrm{G}_{3}$ Member) indicates this final major Early Cimmerian pulse.

The third cycle covers the early Jurassic time interval (global cycle $\mathrm{J} 1$ of Vail et al. 1977). The onset is marked by the widely recognized Hettangian transgression (cf. Hallam 1978) and as mentioned earlier the »Base Jurassic « is seen as a strong seismic reflector within the Danish Subbasin. The transgression led to deposition of shallow water silty clays of the Fjerritslev Formation in the central part of the Norwegian-Danish Basin. The sedimentation of marginal, partly deltaic sands continued however along the margin of the basin (the younger $\mathrm{G}$ members and the Helsingborg Beds) until late Sinemurian time, where extensive marine conditions were established in the basin.

A very analogous development in the sedimentation is seen in northern Germany and Poland during the Late Triassic-Early Jurassic period. NW Poland was only slightly influenced by the Hettangian transgression however, and full marine conditions in the Polish Basin were not established before the Lower 


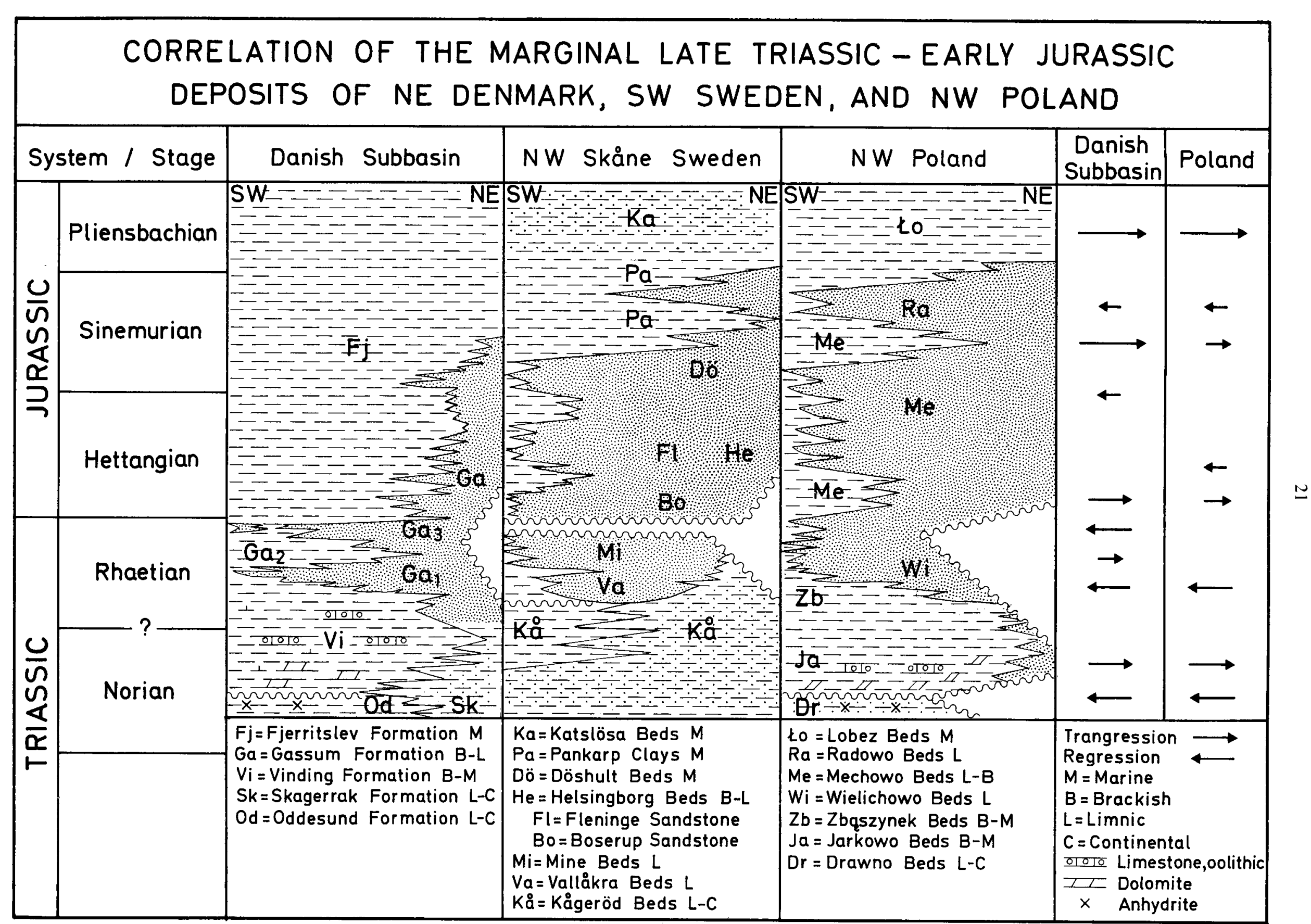

Fig. 9. Correlation of the marginal late Triassic-early Jurassic deposits of NE Denmark, SW Sweden and NW Poland. The Skåne model is based mainly on Troedsson (1951) and Norling (1972). The Polish model is illustrative of the Pomerania Through and the East European Platform margin and is based on Dadlez (1976a \& 1976b). 
Pliensbachian (Carixian) transgression.

The contemporaneous onset of transgressions and the similarity in the cyclical development of the sedimentation which is indicated in the NorwegianDanish Basin, the North German Basin and the Polish Basin during Norian-Sinemurian (fig. 9) is interpreted as due to a function of eustatic sea level changes rather than the effect of local tectonic events. The models described by Vail et al. (1977) and Hallam (1978) therefore plainly seem applicable to this region. Only in the relatively narrow zone along the shield margin known as the Teisseyre-Tornquist line (Fennoscandian Border Zone and part of the Pomerania Trough) may synsedimentary tectonic movements have been of major importance for the course of the sedimentation.

\section{Dansk sammendrag}

\section{De $\emptyset v r e$ triassiske - nedre jurassiske Vinding og Gassum formationer i det Norsk-danske Bassin}

Data fra en række nyere boringer i det Norsk-danske Bassin har givet anledning til en revision og genbeskrivelse af de øvre triassiske-nedre jurassiske Vinding og Gassum Formationer, oprindelig beskrevet af Larsen (1966). Genbeskrivelsen omfatter følgende punkter: Revision af typeprofil og oprettelse af reference profiler, kortfattet lithologisk beskrivelse, beskrivelse af wire line logmotiver og deres brug ved grænsedragninger, geologisk alder, samt tolkning af bassinudvikling og aflejringsmiljø. Endvidere foretages en sammenligning med de jævnaldrende dannelser i det Nordtyske og Polske Bassin.

Vinding Formationen kan kort karakteriseres som en marin, brak, lavtvandsdannelse af mørkegrå lersten med indlejrede tynde kalksten. Hyppigt ses bænke af mikrokrystalline, dolomitiske kalksten ved basis, medens oolithiske kalksten typisk optræder i det mellemste afsnit. Formationens mægtighed og udbredelse fremgår af fig. 5. Alderen kan på basis af analyser af ostracodfaunaer og palynomorpher bedømmes til norien-rhaetien. Vinding Formationen overlejres conformt af Gassum Formationen.

Gassum Formationen er en fluvio-deltaisk dannelse af ensidig nordlig og østlig oprindelse. I den sydlige og centrale del af bassinet kan den inddeles $i$ tre members $\left(G_{1}, G_{2}\right.$ og $\left.G_{3}\right)$, medens en række yngre members kan erkendes $\mathrm{i}$ de nordlige jyske boringer. $\mathrm{G}_{1}$ er formationens basale og mægtigste sandstensmember, svarende til Mittelrhaet Hauptsandstein i det Nordtyske Bassin. $G_{2}$ er opbygget af mørke, organisk rige lersten. $G_{3}$ member omfatter rødlige, brunlige og lyst grågrønne lersten og lyse, glimmerrige tildels glaukonitførende, finkornede sandsten, der kan jævnføres med Triletes Schichten (Oberrhaet Sandstein) i Nordtyskland. De yngre members består af vekslende, ofte kulførende, lersten og sandsten, der kan sammenlignes med Helsingborg lagene i NV Skåne. Formationens udbredelse og mægtighed er vist på fig. 7. Formationen er diachron. $\mathrm{G}_{1}$ til $\mathrm{G}_{3}$ kan ved hjælp af palynomorpher dateres til rhaetien-nedre hettangien, medens de yngre members er af hettangien-sinemurien alder.

Et særligt afsnit er viet Ringkøbing-Fyn Højderyggens rolle $\mathrm{i}$ bassinudviklingen. Det påvises, at der er en nøje parallellitet mellem den sedimentologiske udvikling i bassinerne nord og syd for RingkøbingFyn Højderyggen, samt at sidstnævnte struktur næppe har fungeret som barriere mellem bassinerne og ej heller synes at have været kildeområde for sedimenttilførsel til det Danske Sub-bassin. Formationernes manglende tilstedeværelse over dele af Højderyggen og dens forlængelse i Møn-Arkona blokken tolkes som et resultat af Midt-Cimmerisk hævning ved overgangen til mellem jura med påfølgende mellem til øvre jurassisk erosion.

Endelig sammenfattes aflejringsforløbet og sættes i sammenhæng med større regionale hændelser, såsom en gradvis klimaændring fra semiaride til humide forhold ved trias-jura overgangen samt relativ hævning og sænkning af vandspejlet som følge af tidlig Cimmeriske globale skorpe-bevægelser. Tre sedimentationscykler, hver især startende med en transgressiv og sluttende med en regressiv fase, kan påvises: Første cyclus omfatter aflejring af Vinding Formationen og $\mathrm{G}_{1}$ member, anden cyclus omfatter $\mathrm{G}_{2}$ og $\mathrm{G}_{3}$ members, medens tredje cyclus der varer til udgangen af nedre jura indledningsvis omfatter de yngre members af Gassum Formationen i Nordjylland og iøvrigt hele Fjerritslev Formationen samt Haldager Formationen. 


\section{Acknowledgements}

The author would like to thank dr. phil. Leif Banke Rasmussen, Head of the Department for Subsurface Geology, for his encouragement and for permission to publish the results. Thank are also given to my colleagues dr. phil. Olaf Michelsen and cand. scient. Søren Priisholm for valuable criticism of the manuscript.

I am grateful to Ms. Vibeke Hermansen and to Ms. Lene Kristensen for typing the manuscript, and to Ms. Eva Melskens for drawing the illustrations.

Cand. scient. Mike Robson corrected the English manuscript. 


\section{Selected bibliography}

Andersen, O.B., Larsen, B. \& Platou, S.W., 1975. Gravity and geological structure of the Fennoscandian Border-Zone in the southern Baltic Sea. Bull. geol. Soc. Denmark, 24, pp. 45-53.

Baartman, J.C. \& Christensen, O.B., 1975. Contributions to the interpretation of the Fennoscandian Border Zone. - Danm. geol. Unders., II rk., 102, 47 pp.

Batten, D.J., 1976. Wealden of the Weald - a new model. - Proc. Geol. Ass., 87, pp. 431-433.

Bertelsen, F., 1975. Triassic palynology and stratigraphy of some Danish North Sea boreholes. - Danm. geol. Unders., Årbog 1974, pp. 17-32.

Bertelsen, F. \& Michelsen, O., 1970. Megaspores and ostracods from the Rhaeto-Liassic section in the boring Rødby No. 1, southern Denmark. - Danm. geol. Unders., II rk., 94, 60 pp.

Bjelm, L., Hartlen, J., Röshoff, K., Bennet, J., Bruch, H., Persson, P-G. \& Wadstein, P., 1977. - Geotermisk energiudvinning i Skåne, slutrapport etapp 1. Rep. published by Tekniska högskolan i Lund, Sweden.

Brotzen, F., 1950. De geologiska resultaten från borrningarna vid Höllviken, Del II. Undre Krian och Trias. - Sver. geol. Unders., Ser. C. No. 505,48 pp.

Bölau, E., 1959. Der Südwest- und Südostrand des Baltischen Schildes (Schonen und Ostbaltikum). - Geol. Fören. Förhandl., 81, pp. 167-230.

Bölau, E., 1969. Tektonische und klimatische Ausdeutung von Faziesgegensätzen im Rhät Schonens. - Geol. Fören. Förhandl., 91, pp. 561-573.

Christensen, O.B., 1962. Ostracodtyper fra Keuper-Rhaet lagserien i dybdeboringerne ved Harte og Ullerslev. - Medd. Dansk Geol. Foren., 15, pp. 90-99.

Christensen, O.B., 1963. Ostracoder fra Keuper-Rhaet i nogle danske dybdeboringer. - Medd. Dansk Geol. Foren., 15, p. 240.

Christensen, O.B., 1971. Biostratigrafisk undersøgelse af trias i Rønde nr. 1 og trias-jura grænseområdet. - Danm. geol. Unders. III rk., 39, pp. 89-93.

Christensen, O.B., 1972. Det danske sænkningsområdes udvikling i det mellemste Mesozoikum. - Dansk geol. Foren., Årskrift for 1971, pp. 55-62.

Christensen, O.B., 1973. Vinding formationen ( $\varnothing v r e$ trias) $\mathrm{i}$ Nøvling nr. 1. - Danm. geol. Unders., III rk., 40, pp. 132-135.

Dadlez, R., 1964. (The stratigraphy and course of sedimentation of the Keuper and Lower Jurassic on the base of the Mechowo IG I borehole). Inst. Geol. Bull., 189, 61-92. (In Polish w/English Résumé).

Dadlez, R., 1974. Some geological problems of the Southern Baltic Basin. - Acta Geol. Polon., 24, pp. 261-275.

Dadlez, R., 1976a. Lower Jurassic. In: Sokolowski, S. (edit.): Geology of Poland, 1 (2), pp. 156-163 and pp. 199-241. - Geol. Inst., Wydawnicta Geologiczne, Warszawa.

Dadlez, R., 1976b. Retyk i lias. In: Dadlez, R. (edit.): Permian and Mesozoic of the Pomerania Trough. - Prace Geol. Inst., 79, pp. 64-71. (In Polish w/ English résumé).

Dadlez, R. \& Kopik, J., 1975. Stratigraphy and palaeogeography of the Jurassic. - Geol. Inst. Bull., 252, pp. 149-171.

Deegan, C.E. \& Scull, B.J. (compilers), 1977. A proposed standard lithostratigraphic nomenclature for the Central and Northern North Sea. - Rep. Inst. Geol. Sci., No. 77/25.

Dinesen, A., 1971. Trias i Rønde nr. 1 (2614-4643m). Lithologisk beskrivelse og inddeling. - Danm. geol. Unders., III rk., 39, pp. 94-107.

Dinesen, A., 1973. Trias i Nøvling nr. 1 (1847-3423m). - Danm. geol. Unders., III rk., 40, pp. 136-145.
Floden, T., 1973. Notes on the bedrock of the eastern Skagerrak with remarks on the Pleistocene deposits. - Stockh. Contr. Geol., 24, pp. 79-102.

Gry, H., 1969. Megaspores from the Jurassic of the Island of Bornholm, Denmark. - Medd. Dansk Geol. Foren., 19, pp. 6989.

Hallam, A., 1978. Eustatic cycles in the Jurassic. - Palaeogeo., Palaeoclimat., Palaeoecol., 23, pp. 1-23.

Häusser, I. \& Kurze, M., 1975. Sedimentationsbedingungen und Schwermineralführung im Mesozoikum des Nordteils der DDR. - Z. geol. Wiss., 10, pp. 1317-1332.

Kopik, J., 1976. Rhaetian. In: Sokolowski, S. (edit.): Geology of Poland, 1 (2), pp. 94-100. - Geol. Inst., Wydawnictwa Geologiczne, Warszawa.

Kölbel, H., 1967. Die Paläogeographie des Juras im Nordteil der DDR in Beziehung zu den nachbargebieten. - Ber. deutsch. Ges. geol. Wiss., A, Geol. Paläont., 12, pp. 259-288.

Larsen, G., 1966. Rhaetic-Jurassic-Lower Cretaceous sediments in the Danish Embayment (A heavy mineral study). - Danm. geol. Unders., II rk. 91, 127 pp.

Larsen, G., Christensen, O.B., Bang, I. \& Buch, A., 1968. Øresund, Helsingør-Helsingborg linien. - Danm. geol. Unders., Rapp. No. 1, 90 pp.

Lund, J.J., 1977. Rhaetic to Lower Liassic palynology of the onshore southeastern North Sea Basin. - Danm. geol. Unders., II rk., 109, 129 pp.

Lundblad, B., 1956. On the stratigraphical value of the megaspores of Lycostrobus scottii. - Sver. geol. Unders., Ser. C., No. 547, $11 \mathrm{pp}$.

Mahin, K., 1968. Sporenpaläontologischer Nachweis von mittlerer Jura in der Bohrung von Höllviken I, Südschweden. - Geol. Fören. Förhandl., 90, pp. 121-124.

Marcinkiewicz, T., 1971. The stratigraphy of the Rhaetian and Lias in Poland based on megaspore investigations. - Prace Geol. Inst., 65, 37 pp. (In Polish w/English Résumé).

Michelsen, O., 1973. On Liassic holothurian and ostracod assemblages from the Danish Embayment. - Danm. geol. Unders., Årbog 1972, pp. 49-68.

Michelsen, O., 1975. Lower Jurassic biostratigraphy and ostracods of the Danish Embayment. - Danm. geol. Unders., II rk., 104, $287 \mathrm{pp}$.

Michelsen, O., 1978. Stratigraphy and distribution of Jurassic deposits of the Norwegian-Danish Basin. - Danm. geol. Unders., Ser. B., No. 2, 29 pp.

Mörner, N.A., 1969. The late Quaternary history of the Kattegat Sea and the Swedish west coast. - Sver. geol. Unders., Ser. C., No. $640,487 \mathrm{pp}$.

Nilsson, K., 1966. Geological data from the Kristianstad plain, southern Sweden. - Sver. geol. Unders., Ser. C., No. 605, 32 pp.

Norling, E., 1972. Jurassic stratigraphy and foraminifera of western Scania, southern Sweden. - Sver. geol. Unders., Ser. Ca, No. 47,120 pp.

Rusitzka, D., 1967. Paläogeographie der Trias im Nordteil der DDR. - Ber. deutsch. Ges. geol. Wiss., A, Geol. Paläont., 12, pp. 243-257.

Schlumberger, 1974. Well evaluation conference North Sea. 171 pp. France.

Schott, W., 1942. Die Gliederung im nordwestdeutschen Rätbecken. - Ber. Reichsamts f. Bodenforșch., Jg. 1942, pp. 61-77.

Schumacher, K-H. \& Sonntag, H., 1964. Zur Stratigraphie und Ausbildung des Lias im Norden der Deutschen Demokratischen Republik. - Geologie Jg. 13, pp. 303-315. 
Seitz, O. \& Wicher, C.A., 1950. Über die im Bereich der Tempelburger Struktur gestossenen Tiefborungen und ihre Bedeutung für die Stratigraphie und Paläogeographie der Trias. - Geol. Jb., 65, pp. 463-496.

Selley, R.C., 1975. Subsurface diagnosis of deltaic deposits with reference to the Northern North Sea. - Proc. Jurassic Northern North Sea Symposium 1975, 13, pp. 1-21. Publ. by Norwegian Petrol. Soc.

Sellwood, B.W., 1972. Tidal-flat sedimentation in the Lower Jurassic of Bornholm, Denmark. - Palaeogeography, Palaeoclimatol., Palaeoecol., 11, pp. 93-106.

Senkowiczowa, H. \& Szyperko-Sliwczyńska, A., 1975. Stratigraphy and palaeogeography of the Trias. - Geol. Inst. Bull., 252, pp. 131-147.

Sokolowski, S. (editor), 1976. Geology of Poland, vol. 1, part 2: Mesozoic. 859 pp. - Published by Wydawnictwa Geologiczne, Warszawa.

Sorgenfrei, T. \& Buch, A., 1964. Deep tests in Denmark 1935-1959. - Danm. geol. Unders., III rk., 36, 146 pp.

Troedsson, G., 1951. On the Höganäs series of Sweden (RhaetoLias), - Lunds Univ. Årsskr. N.F. Avd. 2, 47, pp. 3-268.

Vail, P.R., Mitchum, R.M. \& Todd, R.G. 1977. Eustatic model for the North Sea during the Mesozoic. In proceadings of the NPF - Mesozoic Northern North Sea. Symposium Oslo 1977, pp. 12/1-22. Published by the Norwegian Petroleum Society, Norway.

Vossmerbäumer, H., 1970. Untersuchungen zur Bildungsgeschichte des Unteren Lias in Schonen (Schweden). - Geol. Palaeont., 4, pp. 167-193.

Will, H-J., 1969. Untersuchungen zur Stratigraphie und Genese des Oberkeupers in Nordwestdeutschland. - Beih. Geol. Jb., $54,239 \mathrm{pp}$.

Ziegler, P., 1977. Geology and hydrocarbon provinces of the North Sea. - GeoJournal 1, pp. 7-32. 
VINDING FORMATION WELL DATA

Table 1

Well

Depth b. KB

(m or feet)

Dansk Nordsø K-1

Gassum 1

Harte 2

Horsens 1

Mors 1

Nøvling 1

Rødby $1^{*}$

Rødby 2*

Rønde 1

Slagelse 1

Thisted 1

Tønder 2*

Ullerslev 1

Vemb 1

Vinding 1

Åbenrå 1*

$6735-6869^{\prime}$
$5406-5590^{\prime}$
$3103-3173^{\prime}$
$1600-1645 \mathrm{~m}$
$2934.6-3023.4 \mathrm{~m}$
$1932.0-1998.0 \mathrm{~m}$
$2260-2350^{\prime}$
$2208-2292^{\prime}$
$2753.0-2824.6 \mathrm{~m}$
$1287-1338 \mathrm{~m}$
$871.0-935.1 \mathrm{~m}$
$3675-3825^{\prime}$
$3088-3221^{\prime}$
$1853-1894 \mathrm{~m}$
$5420-5610^{\prime}$
$3108-3123^{\prime}$

$\begin{array}{lc}\begin{array}{l}\text { Log-type } \\ \text { (top/base) }\end{array} & \text { Log scale } \\ & \\ \text { SP+Res/SP+Res } & 1: 200 \\ \text { GR+core description } & 1: 500 \\ \text { Mud log/Mud log } & \\ \text { SP+(Res)/SP+(Res) } & 1: 1000 \\ \text { GR+(ITT)/GR+(ITT) } & 1: 200 \\ \text { ITT/ITT } & 1: 200 \\ \text { SP+(Res)/SP+(Res) } & 1: 500 \\ \text { SP+(Res)/SP+(Res) } & 1: 500 \\ \text { (GR)+N/(GR)+N } & 1: 200 \\ \text { GR+N/GR+N } & 1: 1000 \\ \text { GR+(ITT)/GR+(ITT) } & 1: 200 \\ \text { SP+(Res)/SP+(Res) } & 1: 500 \\ \text { SP+(Res)/SP+(Res) } & 1: 500 \\ \text { SP+(Res)/SP+(Res) } & 1: 1000 \\ \text { Mud log + drill. rate } & \\ \text { SP+(Res)/SP+(Res) } & 1: 500\end{array}$

$\begin{array}{cc}\begin{array}{l}\text { Depth b. } \\ \text { MSL m }\end{array} & \begin{array}{l}\text { Thick- } \\ \text { ness }\end{array} \\ & \\ 2016-2057 & 41 \\ 1590-1646 & 56 \\ 915-936 & -21 \\ 1543-1588 & 45 \\ 2917-3005 & 89 \\ 1863-1929 & 66 \\ 683-711 & 27 \\ 665-691 & 26 \\ 2711-2782 & 72 \\ 1246-1297 & 51 \\ 835-899 & 64 \\ 1103-1149 & 46 \\ 916-957 & 41 \\ 1837-1878 & 41 \\ 1591-1648 & 58 \\ 891-896 & -5\end{array}$

* wells situated on the southern flank of the Ringkøbing-Fyn High.

Legend: Log types used for definition of upper/lower boundary

GR = Gamma Ray; ITT = Interval Transit Time; SP = Spontaneous Potential; Res $=$ Resistivity; N $=$ Neutron; TD $=$ Total depth of well; KB = Kelly Bushing; MSL = Mean Sea Level.

Thicknesses are calculated from the log readings (b. KB)

- indicates that the upper part of the formation is missing (unconformity)

+ indicates that the formation has not been penetrated

GASSUM FORMATION WELL DATA

Table 2

$\begin{array}{ll}\text { Well } & \begin{array}{l}\text { Depth b. KB } \\ \text { (m or feet) }\end{array} \\ \text { Børglum 1 } & 4500-5010^{\prime} \\ \text { Dansk Nordsø F-1 } & 6818-7068^{\prime} \\ \text { Dansk Nordsø J-1 } & 5688.5-5925^{\prime} \\ \text { Dansk Nordsø K-1 } & 6514-6735^{\prime} \\ \text { Fjerritslev 2 } & 2233-2329 \mathrm{~m}^{\prime} \\ \text { Flyvbjerg 1 } & 1308-1504 \mathrm{~m} \\ \text { Frederikshavn 1 } & 2973-3227^{\prime} \\ \text { Frederikshavn 2 } & 2903-3160^{\prime} \\ \text { Frederikshavn 3 } & 2855-3065^{\prime} \\ \text { Gassum 1 } & 4980-5406^{\prime} \\ \text { Horsens 1 } & 1506-1600 \mathrm{~m} \\ \text { Lavø 1 } & 2133-2368 \mathrm{~m} \\ \text { Mors 1 } & 2768.4-2934.6 \mathrm{~m} \\ \text { Nøvling 1 } & 1847.0-1932.0 \mathrm{~m} \\ \text { Rødby 1* } & 1549-2260^{\prime} \\ \text { Rødby 2* } & 1486-2208^{\prime} \\ \text { Rønde 1 } & 2613.6-2753.0 \mathrm{~m} \\ \text { Skagen 2 } & 1817-1854^{\prime} \\ \text { Slagelse 1 } & 1150-1287 \mathrm{~m} \\ \text { Thisted 1 } & 746.0-871.0 \mathrm{~m} \\ \text { Tønder 2* } & 3566-3675^{\prime} \\ \text { Ullerslev 1 } & 2763-3088^{\prime} \\ \text { Vedsted 1 } & 1897.5-2037.5 \mathrm{~m} \\ \text { Vemb 1 } & 1795-1853 \mathrm{~m} \\ \text { Vinding 1 } & 5252-5420^{\prime} \\ \text { Ørslev 1* } & 523.1-744.0 \mathrm{~m}\end{array}$

$\begin{array}{lr}\begin{array}{l}\text { Log-type } \\ \text { (top/base) }\end{array} & \text { Log scale } \\ & \\ \text { SP+Res/(TD) } & 1: 500 \\ \text { GR+ITT/GR+ITT } & 1: 200 \\ \text { GR+ITT/GR+ITT } & 1: 200 \\ \text { SP+Res/SP+Res } & 1: 200 \\ \text { Mud log/Mud log } & \\ \text { SP+Res/SP+Res } & 1: 1000 \\ \text { SP+Res/SP+Res } & 1: 500 \\ \text { SP+Res/SP+Res } & 1: 500 \\ \text { SP+Res/SP+Res } & 1: 500 \\ \text { GR+Mud log/GR+Mud log } & 1: 500 \\ \text { SP+(Res)/SP+(Res) } & 1: 1000 \\ \text { SP+(Res)/SP+(Res) } & 1: 1000 \\ \text { (GR)+ITT/GR+(ITT) } & 1: 200 \\ \text { ITT/ITT } & 1: 200 \\ \text { SP+(Res)/SP+(Res) } & 1: 500 \\ \text { SP+(Res)/SP+(Res) } & 1: 500 \\ \text { GR+N/(GR)+N } & 1: 200 \\ \text { Core description } & \\ \text { GR+(N)/GR+N } & 1: 1000 \\ \text { (GR)+ITT/GR+(ITT) } & 1: 200 \\ \text { SP+(Res)/SP+(Res) } & 1: 500 \\ \text { SP+(Res)/SP+(Res) } & 1: 500 \\ \text { SP+(Res)/SP+(Res) } & 1: 1000 \\ \text { SP+Res/SP+(Res) } & 1: 1000 \\ \text { Mud log + drill. rate } & \\ \text { (GR)+ITT/(GR)+ITT } & 1: 200 \\ & \end{array}$

* wells situated on the southern flank of the Ringkøbing-Fyn High

$\begin{array}{cc}\begin{array}{cc}\text { Depth b. } \\ \text { MSL m }\end{array} & \begin{array}{c}\text { Thick- } \\ \text { ness }\end{array} \\ & \\ 1349-1505 & 156^{+} \\ 2041-2117 & 76 \\ 1697-1769 & 72 \\ 1948-2016 & 67 \\ 2225-2321 & 96 ? \\ 1261-1457 & 196 \\ 893-971 & 77 \\ 869-948 & 78 \\ 860-924 & 64 \\ 1460-1590 & 130 \\ 1449-1543 & 94 \\ 2105-2340 & 235 \\ 2750-2917 & 166 \\ 1778-1863 & 85 \\ 467-683 & 217 \\ 445-665 & 220 \\ 2571-2711 & 139 \\ 552-563 & 11 \\ 1109-1246 & 137 \\ 710-835 & 125 \\ 1070-1103 & -33 \\ 817-916 & 99 \\ 1892-2032 & 140 \\ 1779-1837 & 58 \\ 1539-1591 & 51 \\ 500-721 & 221 \\ & \end{array}$

